\title{
Reproductive number of COVID-19: A systematic review and meta-analysis based on global level evidence
}

\author{
Md. Arif Billah ${ }^{1}$, MSc; Md. Mamun Miah ${ }^{2}$, MSc, Md. Nuruzzaman Khan ${ }^{3}$, MSc \\ ${ }^{1}$ Faculty of Business, Economic and Social Development, University Malaysia Terengganu, \\ Malaysia \\ ${ }^{2}$ Department of Mathematics, Khulna University of Engineering and Technology, Khulna, \\ Bangladesh. \\ ${ }^{3}$ Department of Population Sciences, Jatiya Kabi Kazi Nazrul Islam University, Trishal, \\ Mymensingh-2220, Bangladesh
}

Short running title: Reproductive number of COVID-19

\section{*Corresponding Author:}

Md. Nuruzzaman Khan, MSc

Lecturer

Department of Population Sciences

Jatiya Kabi Kazi Nazrul Islam University, Trishal, Mymensingh, Bangladesh.

E-mail: sumonrupop@gmail.com

\author{
Abbreviations \\ COVID-19 Novel Coronavirus 2019 \\ EGR Exponential Growth Rate \\ MCMC Markov Chain Monte Carlo \\ MERS Middle East Respiratory Syndrome \\ MLE Maximum Likelihood Estimation \\ SARS Severe Acute Respiratory Syndrome \\ SEIR Susceptible, Exposed, Infected and Removed/Recovered \\ SIR Susceptible, Infected and Removed/Recovered
}




\section{Reproductive number of COVID-19: A systematic review and meta-analysis based on global level evidence}

\section{Abstract \\ Background}

The coronavirus (COVID-19) is now a global concern because of its higher transmission capacity and associated adverse consequences including death. The reproductive number of COVID-19 provides an estimate on possible extent of the transmission. This study aims to provide the average reproductive number of COVID-19 based on available global level evidence.

\section{Methods}

We searched three databases (PubMed, Web of Science, and Science Direct) to find studies reported the reproductive number of COVID-19. The searches were conducted using a prespecified search strategy that includes keywords of COVID-19 and its reproductive number related terms, which were combined using the Boolean operators. We used meta-analysis to provide average reproduction number of COVID-19.

\section{Results}

Total of 30 studies included in this review whereas 24 of them were included in the metaanalysis. The average estimated reproductive number was 2.70 (95\% CI, 2.21-3.30). We found evidence of very high heterogeneity $(99.5 \%)$ of the reproductive number reported in the included studies. The highest reproductive number was reported for Diamond Princes Cruise Ship, Japan (14.8). In the country-level, higher reproductive number was reported for France (R, 6.32, 95\% CI, 5.72-6.98) following Germany (R, 6.07, 95\% CI, 5.51-6.69) and Spain (R, 5.08, 95\% CI, 4.50-5.73). We also found estimation models, methods, and the number of cases considered to estimate reproductive number were played a role in arising the heterogeneity of the estimated reproductive number. 
medRxiv preprint doi: https://doi.org/10.1101/2020.05.23.20111021; this version posted May 31, 2020. The copyright holder for this preprint (which was not certified by peer review) is the author/funder, who has granted medRxiv a license to display the preprint in perpetuity.

It is made available under a CC-BY-NC 4.0 International license .

\section{Conclusion}

The estimated reproductive number indicates an exponential increase of COVID-19 infection in coming days. Comprehensive policies and programs are important to reduce new infections as well as the associated adverse consequences including death.

Keywords: Coronavirus (COVID-19), Reproductive number, systematic review, metaanalysis 
medRxiv preprint doi: https://doi.org/10.1101/2020.05.23.20111021; this version posted May 31, 2020. The copyright holder for this preprint

\section{Background}

Coronavirus (COVID-19) is now a global concern that speared out to 213 countries or territories as of May 30, 2020. More than 6 million population have been infected so far worldwide, of which more than 367,304 are died [1]. Consequently, the World Health Organization has declared it as pandemic and suggested countries to take aggressive measures to reduce new infections [2]. Given no treatments or vaccines available for this virus, countries are now also taking numerous non-medical measures to reduce further infections, which include restricting people's movements, banned international and local travels, quarantine, and isolation [3]. However, the new infections are rising exponentially, in all ages and sexes, irrespective of countries [4,5]. Reducing new infections, therefore, needs further comprehensive preventive measures.

The virus was first discovered by Tyrrell and Bynoe in 1965 in the human respiratory tract of an adult infected with the common cold [6]. Since then the virus caused three major largescale outbreaks, namely, Severe Acute Respiratory Syndrome (SARS) in 2003 in mainland China [7], Middle East Respiratory Syndrome (MERS) in 2012 in Saudi-Arabia [8], and MERS in 2015 in South Korea [9]. These outbreaks showed some similar characteristics which are common with current COVID-19 outbreak, such as fever, cough, and the breathing difficulties [10].

This round of coronavirus appeared from a single center in a seafood market of Wuhan, China [11]. Two families consisting of five people or healthcare workers infected initially from the seafood market and visited a nearest healthcare center, from where the virus was spread rapidly to other people (nosocomial) through human-to-human transmission [12-16]. The virus then spread out worldwide through international travelers from China (Figure 1) [17]. 


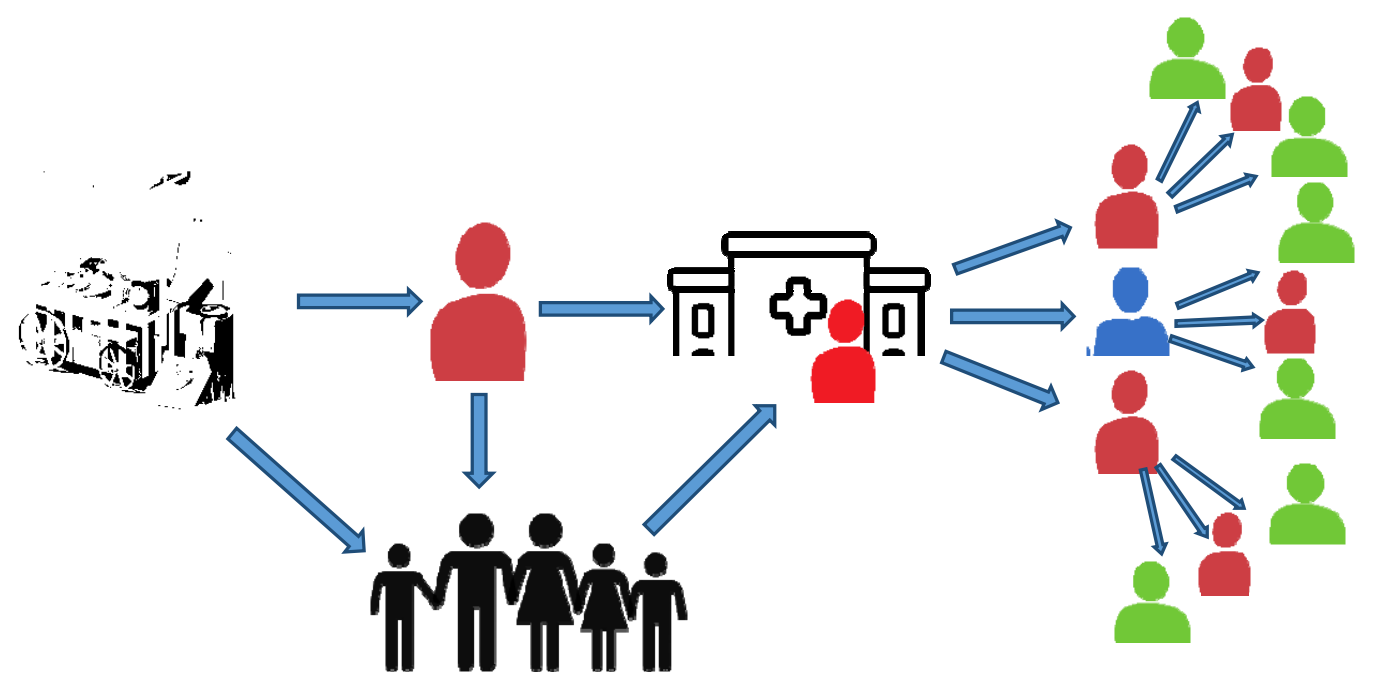

Figure 1: The probable ways of the COVID-19 transmission into the human and turned into a person-to-person transmission process (The seafood shop was the center from where the virus transmitted into customers or sellers or both. The symptoms of the infection were normal cold, headache, and pneumonia. The infected persons then transmitted the virus to noninfected in two different routes: (a). Infected persons went to the nearby hospital for treatment. Clinical manifestations were not examined properly and the infected persons presented risk to transmission among non-infected hospital attendances (b). Infection also transmitted into the infected person family members. The virus was then spread out worldwide, at the end of February 2020, through the infected international travelers from China).

Knowing the accurate reproductive number of COVID-19, which means the capability of transmission per primary infected person to the secondarily infected persons, is significant for various reasons: to assess epidemic transmissibility and to predict the future trend of spreading [18]. These are important to reduce new infections and to design control measures such as social distancing [19] and to know the duration of keeping control measures [5]. Moreover, it also helps to develop an effective epidemiological mathematical models considering possible transmission ways, such as, droplets and direct contacts with COVID-19 infected people, which are important to know the risk population and the appropriate epidemiologic parameters [20,21]. 
medRxiv preprint doi: https://doi.org/10.1101/2020.05.23.20111021; this version posted May 31, 2020. The copyright holder for this preprint

Various researchers worldwide estimated reproductive number of COVID-19. However, these were not consistent and measurement procedures and methods were different across the studies [20,22]. The reproductive number estimated was also found different across the countries, stages of infection, and the preventive measures applied [23]. Another important source of variation of estimated reproductive number was type of reproductive numbers considered [20]. Of the three reproductive numbers estimated, namely basic reproductive number $\left(R_{0}\right)$, net reproductive number $\left(R_{e}\right)$, and time dependent reproductive number $\left(R_{t}\right)$, are applicable for different purposes. For instance, the basic reproductive number is used when an infected person can mix randomly to non-infected persons (i.e no control intervention was applied), whereas, the net and time-dependent reproductive number are used when control interventions were applied. Consequently, these three reproductive numbers are also followed different distributions of infection period. However, the value of each reproductive number ranges from zero to any positive number, where $R<1$ indicates new infection will decrease, $R=0$ indicates the stability of new infection, and $R>1$ indicates new infection will increase [24,25].

Considering the higher variability of the reproductive number estimated and its underlying importance, in this study, an attempt has been made to summarize available reproductive number of COVID-19 to give an average estimate. If applicable, sources of variations of the estimated reproductive number will also be addressed. Findings will help policymakers to know about the possible increase of COVID-19's patients and take policies and programs accordingly.

\section{Methods}

Literature searches were conducted in three databases on April 10, 2020: PubMed, Web of Science, and Science Direct. The pre-specified search strategies were used to search 
medRxiv preprint doi: https://doi.org/10.1101/2020.05.23.20111021; this version posted May 31, 2020. The copyright holder for this preprint

databases (Supplementary Tables 1-3). We developed search strategies consisting of virusspecific (corona virus, coronavirus, SARS-CoV-2, COVID-19, nCoV-2019) and reproductive number related (reproduction number, transmissibility) keywords that were combined using the Boolean operators (AND, OR). Additional searches were conducted in the reference list of the selected articles, and the relevant journal's websites.

\section{Inclusion and exclusion criteria}

Studies meet the following inclusion criteria were included: wrote in the English language, related to COVID-19, and presented the reproductive number of COVID-19. We did not apply any time restriction, i.e. all studies from the onset of COVID-19 to the date of conducting formal search were included. Studies that did not meet these criteria were excluded.

\section{Data extraction and analysis}

Two authors (MAB, MMM) extracted information by using a pre-designed, trailed, and modified data extraction sheet. The extracted information includes: year of publication, study's location, model used to estimate the reproductive number, time period for when the reproductive number was estimated, number of cases considered to estimate the reproductive number, assumption(s) that was/were set to a calculate the reproductive number, intervention strategy, and the estimated reproductive number with its $95 \%$ confidence interval (CI). The corresponding author (MNK) solved any disagreement on information extraction.

The information recorded were mostly dichotomous in nature where the numerical reproductive number was reported in all selected studies. We, therefore, used both narrative synthesis and meta-analysis to summaries findings from retrieved studies. Narrative synthesis used initially to describe assumptions applied in estimating the reproductive number, number of cases used to estimate reproductive number, time/period for when the reproductive number 
estimated, and the models and methods used to estimate the reproductive number. Metaanalysis then used to give an average estimate of the reproductive number. We used both fixed effect and random effect model to summarize the reproductive number selected based on heterogeneity assessment $\left(I^{2}\right)$. We used fixed effect model if the heterogeneity was low $\left(I^{2}<50 \%\right)$ and the random effect model if the heterogeneity was moderate $\left(I^{2}>50 \%\right)$ or high $\left(I^{2}>75 \%\right)$. For the studies where more than one reproductive number reported based on different assumptions, we calculated the average reproductive number. This calculated average reproductive number was then used to give summary estimate of the reproductive number. Heterogeneity of the average estimated reproductive number was assessed through sub-groups analysis across the selected studies' characteristics. We also assessed the publication bias through visual inspection of the funnel plot and Egger's regression asymmetry test. Trim-and-Fill procedure was used when evidence of publication bias was found. The National Institutes of Health (NIH) study quality assessment tool was used to assess study quality. The Stata software version 15.1 (Stata Corp, College Station, Texas, USA) was used to perform all analyses.

\section{Results}

\section{Literature search results}

Total of 134 studies included, 130 of them were extracted from three databases searched (Figure 2, Supplementary Tables 1-3). Of these, 102 studies were excluded through title and abstract screening leaving 32 studies for full-text review. A total of 30 of them were finally included in this study and 24 of them were included in meta-analysis. All study were high in quality (Supplementary Table 4). 


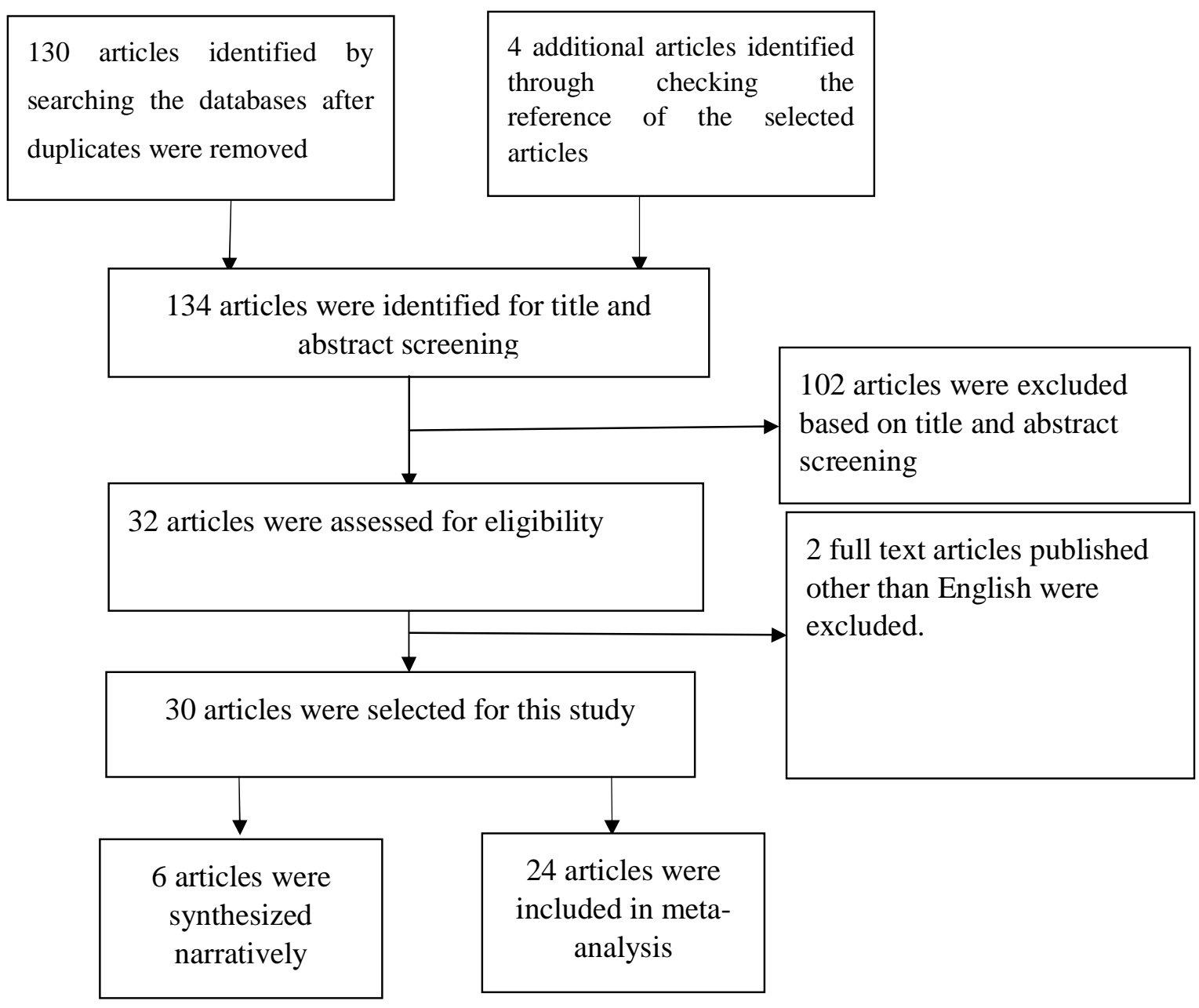

Figure 2. Schematic representation of studies included in the systematic review using the PRISMA checklist and flow diagram

Majority of the studies selected were conducted in China (8) [18,26-32] and its province (6) [33-38]. The remaining studies were conducted in Japan (4) [39-42] followed by South Korea (3) [43-45], Italy (2) [46,47], and France, Germany, and Spain [47]. Four studies included were conducted based on multiple countries' data [19,48-50].

\section{Estimated reproduction number}

Of the 30 studies included in this review reported different reproductive numbers (Table 1). The estimated reproductive number in this analysis was 2.70 (95\% CI, 2.21-3.30) with a very 
high-heterogeneity (99.5\%) (Figure 3). However, we did not find any evidence of publication bias (Supplementary Figure 1). Sub-group analysis was used to address heterogeneity (Table 2, Supplementary Figures 2-5). We found study's characteristics, such as countries for which the reproductive number estimated, models and methods used to estimate the reproductive number, and the number of cases used to estimate reproductive number were played a significant role of arising such heterogeneity (Table 2). For instance, the estimated reproductive number was around double $(\mathrm{R}, 4.56,95 \% \mathrm{CI}, 2.28-9.12)$ in outside of China than China (R, 2.72, 95\% CI, 2.08-3.57). However, in the country level, the highest reproductive number was reported for France ( $\mathrm{R}, 6.32,95 \% \mathrm{CI}, 5.72-6.98)$ following Germany (R, 6.07, 95\% CI, 5.51-6.69) and Spain (R, 5.08, 95\% CI, 4.50-5.73). South Korea was only country reported $<1$ reproductive number of COVID-19 (R, 0.76, 95\% CI, 0.341.70). The higher reproductive number was reported if estimated by the MCMC method (R, 4.18, 95\% CI, 1.75-9.93) and by the Epidemic curve model (R, 2.86, 95\% CI, 2.39-3.42). The average reproductive number found higher if it was estimated for $>3162$ cases $(\mathrm{R}, 2.97,95 \%$ CI, 2.09-4.23) than $\leq 3162$ cases $(\mathrm{R}, 2.50,95 \% \mathrm{CI}, 1.91-3.28)$. 
Table 1: Background characteristics of the studies included in this review

\begin{tabular}{|c|c|c|c|c|c|c|}
\hline $\begin{array}{l}\text { Serial } \\
\text { number }\end{array}$ & $\begin{array}{l}\text { Author, } \\
\text { Study's Location }\end{array}$ & Model & Time/period & Assumption & $\begin{array}{l}\text { Estimation method of } \\
\text { reproductive number } \\
\text { (R) }\end{array}$ & $\mathbf{R}(95 \% \mathbf{C I})$ \\
\hline 1 & $\begin{array}{l}\text { Read et al, } 2020 \text { [50], } \\
\text { China and overseas }\end{array}$ & SEIR model & $\begin{array}{l}1^{\text {st }} \operatorname{Jan} 2020 \text { to } \\
22^{2 \mathrm{dd}} \operatorname{Jan} 2020\end{array}$ & Cases daily time increase follows a Poisson distribution & $\mathrm{MLE}^{1}$ & $3.11(2.39-4.13)$ \\
\hline \multirow{6}{*}{2} & \multirow{6}{*}{$\begin{array}{l}\text { T. Zhou et al, } 2020 \text { [18], } \\
\text { China }^{\mathrm{b}}\end{array}$} & \multirow{6}{*}{ SEIR model } & \multirow{6}{*}{$\begin{array}{l}\text { before 26th } \\
\text { Jan } 2020\end{array}$} & With time generation ${ }^{3}$ of 8.4 days & \multirow{6}{*}{$\mathrm{EGR}^{1}$} & 2.83 \\
\hline & & & & With time generation 10 days & & 3.28 \\
\hline & & & & With time generation of 8.4 days & & 3.22 \\
\hline & & & & With time generation 10 days & & 3.78 \\
\hline & & & & With time generation of 8.4 days & & 3.34 \\
\hline & & & & With time generation 10 days & & 3.93 \\
\hline 3 & $\begin{array}{l}\text { Zhang et al., } 2020[42] \\
\text { Diamond Princess Cruise ship, } \\
\text { Japan }^{\mathrm{a}}\end{array}$ & $\begin{array}{l}\text { Epidemic model } \\
\text { incorporated by the } \\
\text { data }\end{array}$ & 16th Feb 2020 & The mean serial interval ${ }^{2} 7.5$, SD 3.4 days & MLE & $2.28(2.06-2.52)$ \\
\hline \multirow{2}{*}{4} & \multirow{2}{*}{$\begin{array}{l}\text { Liu et al., } 2020 \text { [49], } \\
\text { China and overseas }\end{array}$} & \multirow{2}{*}{$\begin{array}{l}\text { No model } \\
\text { mentioned }\end{array}$} & \multirow{2}{*}{$\begin{array}{l}\text { before 23rd } \\
\text { Jan } 2020\end{array}$} & \multirow{2}{*}{ With time generation of 8.4 days } & EGR & $2.90(2.32-2.52)$ \\
\hline & & & & & MLE & $2.92(2.28-3.67)$ \\
\hline 5 & $\begin{array}{l}\text { Majumder \& Mandl, } 2020 \text { [35], } \\
\text { Wuhan, China }^{\mathrm{a}}\end{array}$ & SIR/IDEA model & $\begin{array}{l}\text { Dec 8, 2019, } \\
\text { to Jan 26, } 2020\end{array}$ & Mean serial interval 8 (range 6-10) days & $\begin{array}{l}\text { The model itself is an } \\
\text { estimation equation }\end{array}$ & $2.55(2.00-3.10)$ \\
\hline 6 & $\begin{array}{l}\text { Riou \& Althaus, } 2020 \text { [19], } \\
\text { China and overseas }\end{array}$ & $\begin{array}{l}\text { No model } \\
\text { mentioned }\end{array}$ & $\begin{array}{l}\text { before } 18^{\text {th }} \text { Jan } \\
2020\end{array}$ & The mean generation time varied 7-14 days & Stochastic simulation & $2.2(1.4-3.8)$ \\
\hline 7 & $\begin{array}{l}\text { Tang et al., } 2020[29] \\
\text { China }^{a}\end{array}$ & $\begin{array}{l}\text { SEIR model (with } \\
\text { isolation, } \\
\text { quarantined) }\end{array}$ & $\begin{array}{l}31 \text { Dec } 2019 \\
\text { to } 15 \text { th Jan } \\
2020\end{array}$ & The incubation period is 7 days & NGMA $^{1}$ & $6.47(5.71-7.23)$ \\
\hline \multirow{3}{*}{8} & \multirow{3}{*}{$\begin{array}{l}\text { Zhao, Lin et al., } 2020 \text { [30], } \\
\text { China }^{a}\end{array}$} & \multirow{3}{*}{$\begin{array}{l}\text { Epidemic curve by } \\
\text { time-series data }\end{array}$} & \multirow{3}{*}{$\begin{array}{l}10^{\text {th }} \text { Jan to } 24^{\text {th }} \\
\text { Jan } 2020\end{array}$} & 8-fold reporting rate & \multirow{3}{*}{ EGR } & $2.24(1.96-2.55)$ \\
\hline & & & & 2 -fold reporting rate & & $3.58(2.89-4.39)$ \\
\hline & & & & 0 -fold reporting rate & & $5.71(4.24-7.54)$ \\
\hline 9 & $\begin{array}{l}\text { Zhao, Musa, et al., } 2020 \text { [31], } \\
\text { China }^{\text {a }}\end{array}$ & $\begin{array}{l}\text { Epidemic curve } \\
\text { using time series } \\
\text { information }\end{array}$ & $\begin{array}{l}1^{\text {st }} \text { Jan to } 15^{\text {th }} \\
\text { Jan } 2020\end{array}$ & $\begin{array}{l}\text { Constant screening effort applied in the Wuhan at the } \\
\text { same point in time. }\end{array}$ & EGR & $2.56(2.49-2.63)$ \\
\hline \multirow{2}{*}{10} & \multirow{2}{*}{$\begin{array}{l}\text { Shen et al., } 2020[36] \\
\text { Hubei province, China }\end{array}$} & \multirow{2}{*}{$\begin{array}{l}\text { SEIR/Dynamic } \\
\text { model }\end{array}$} & \multirow{2}{*}{$\begin{array}{l}12^{\text {th }} \text { Dec } 2019 \\
\text { to } 22 \text { nd Jan } \\
2020\end{array}$} & 5-6 days of incubation & SEIR method ${ }^{1}$ & $4.71(4.50-4.92)$ \\
\hline & & & & With intervention and 5-6 days of incubation period & SEIR method & $2.08(1.99-2.18)$ \\
\hline
\end{tabular}




\begin{tabular}{|c|c|c|c|c|c|c|}
\hline 11 & $\begin{array}{l}\text { Q. Li et al., } 2020 \text { [34], } \\
\text { Wuhan, China }^{a}\end{array}$ & $\begin{array}{l}\text { Epidemiologic time } \\
\text { delay distribution }\end{array}$ & $\begin{array}{l}\text { Before 22nd } \\
\text { Jan } 2020\end{array}$ & Mean serial interval 8.4 and SD 3.8 & $\begin{array}{l}\text { Fitted transmission } \\
\text { model with zoonotic } \\
\text { infection }\end{array}$ & $2.20(1.40-3.90)$ \\
\hline 12 & $\begin{array}{l}\text { J. T. Wu et al., } 2020 \text { [38], } \\
\text { Wuhan, China }^{\mathrm{a}}\end{array}$ & SEIR model & $\begin{array}{l}31 \text { Dec } 2019 \\
\text { to } 28 \text { th Jan } \\
2020\end{array}$ & Mean serial interval of 8.4 & $\mathrm{MCMC}^{1}$ & $2.68(2.47-2.86)$ \\
\hline 13 & $\begin{array}{l}\text { Imai et al., } 2020 \text { [26], } \\
\text { China }^{a}\end{array}$ & $\begin{array}{l}\text { No model } \\
\text { mentioned }\end{array}$ & $\begin{array}{l}\text { before } 18^{\text {th }} \text { Jan } \\
2020\end{array}$ & High level of variability \& generation time is 8.4 days & $\begin{array}{l}\text { Computational modeling } \\
\text { epidemiologic } \\
\text { trajectories }\end{array}$ & $2.60(1.50-3.50)$ \\
\hline 14 & $\begin{array}{l}\text { T.-M. Chen et al., } 2020 \text { [33], } \\
\text { Wuhan, China }^{\mathrm{b}}\end{array}$ & $\begin{array}{l}\text { SEIR (Bat-Host- } \\
\text { Reservoir-People } \\
\text { network model) }\end{array}$ & $\begin{array}{l}10^{\text {th }} \text { Jan to } 24^{\text {th }} \\
\text { Jan } 2020\end{array}$ & Using Reservoir and People network model & NGMA & 3.58 \\
\hline \multirow[b]{2}{*}{15} & \multirow{4}{*}{$\begin{array}{l}\text { Kucharski et al., } 2020 \text { [48], } \\
\text { Wuhan and international } \\
\text { travelers }^{\mathrm{a}} \\
\mathrm{Ki}, 2020 \text { [44], } \\
\text { South Korea } \\
\text { Choi \& Ki, 2020 [43], } \\
\text { South Korea }\end{array}$} & \multirow{3}{*}{$\begin{array}{l}\text { SEIR model } \\
\text { Epidemic curve } \\
\text { fitting }\end{array}$} & \multirow[b]{2}{*}{$\begin{array}{l}\text { 29th Dec } 2019 \\
\text { to } 23 \mathrm{rd} \mathrm{Feb} \\
2020\end{array}$} & $\begin{array}{l}\text { Mean incubation period is assumed to be } 5.2 \& \text { SD } 3.7 \\
\text { days }\end{array}$ & MLE & $2.35(1.15-4.77)$ \\
\hline & & & & $\begin{array}{l}\text { Intervention with mean incubation period } 5.2 \& \text { SD } 3.7 \\
\text { days }\end{array}$ & MLE & $1.05(0.41-2.39)$ \\
\hline 16 & & & $\begin{array}{l}20 \text { Jan to } 10 \\
\text { Feb } 2020\end{array}$ & NA & EGR & $0.48(0.25-0.84)$ \\
\hline 17 & & SEIR & $\begin{array}{l}20 \text { Jan to } 17 \\
\text { Feb,2020 }\end{array}$ & & SEIR method & $0.56(0.51-0.60)$ \\
\hline \multirow[t]{2}{*}{18} & \multirow[t]{2}{*}{$\begin{array}{l}\text { Shim et al., } 2020 \text { [45], } \\
\text { South Korea }^{\mathrm{a}}\end{array}$} & \multirow[t]{2}{*}{$\begin{array}{l}\text { Epidemic curve } \\
\text { fitting with growth } \\
\text { model }\end{array}$} & \multirow[t]{2}{*}{$\begin{array}{l}\text { 20th Jan to } \\
\text { 26th Feb } 2020\end{array}$} & With mean generation time 4.41 and SD 3.17 days & Simulation & $1.50(1.40-1.60)$ \\
\hline & & & & Based on the exponential growth rate of 0.218 per days & EGR & $2.60(2.10-5.10)$ \\
\hline 19 & $\begin{array}{l}\text { Lai et al., } 2020 \text { [51], } \\
\text { Genetic data from GISAID }\end{array}$ & $\begin{array}{l}\text { Phylogenetic } \\
\text { estimation }\end{array}$ & 4th Feb 2020 & $\begin{array}{l}\text { The evolutionary rate set to the value of } 8.0 \times 10-4 \\
\text { subs/site/year }\end{array}$ & $\begin{array}{l}\text { Birth-death skyline } \\
\text { estimate }\end{array}$ & $1.85(1.37-2.40)$ \\
\hline 20 & $\begin{array}{l}\text { Jung et al., } 2020 \text { [52], } \\
\text { Outside of China }^{\mathrm{a}}\end{array}$ & $\begin{array}{l}\text { No model } \\
\text { mentioned }\end{array}$ & $\begin{array}{l}\text { before } 24 \text { Jan } \\
2020\end{array}$ & Mean serial interval 7.5 and SD 3.4 days & EGR & $3.19(2.66-3.69)$ \\
\hline 21 & $\begin{array}{l}\text { W. Zhou et al., } 2020 \text { [32], } \\
\text { China }^{\text {b }}\end{array}$ & $\begin{array}{l}\text { SEIHR model } \\
\text { extended by } \\
\text { quarantined }\end{array}$ & $\begin{array}{l}\text { before } 10 \mathrm{Jan} \\
2020\end{array}$ & A proportion of quarantined exposed by the virus & NGMA & 5.32 \\
\hline \multirow[b]{3}{*}{22} & \multirow{3}{*}{$\begin{array}{l}\text { Song et al., } 2020[28] \text {, } \\
\text { China }^{\mathrm{a}}\end{array}$} & \multirow{3}{*}{ SEIR model } & \multirow{3}{*}{$\begin{array}{l}15 \text { to } 31 \text { Jan } \\
2020\end{array}$} & Using generation intervals & EGR & $3.74(3.63-3.87)$ \\
\hline & & & & Using generation intervals & MLE & $3.16(2.90-3.43)$ \\
\hline & & & & The model fitted best 27 th Jan & SEIR method & $3.91(3.71-4.11)$ \\
\hline \multirow[b]{2}{*}{23} & \multirow{2}{*}{$\begin{array}{l}\text { Sanche et al., } 2020 \text { [27], } \\
\text { China }^{\text {a }}\end{array}$} & \multirow[b]{2}{*}{ SEIR model } & \multirow{2}{*}{$\begin{array}{l}15 \text { to } 30 \text { Jan } \\
2020\end{array}$} & with $7-8$ days of the serial interval & & $5.80(4.40-7.70)$ \\
\hline & & & & with 6-9 days of the serial interval & EGR & $5.7(3.80-8.90)$ \\
\hline 24 & $\begin{array}{l}\text { Mizumoto \& Chowell, } 2020 \\
\text { [40], } \\
\text { Diamond Princes Cruise ship, }\end{array}$ & $\begin{array}{l}\text { No model } \\
\text { mentioned }\end{array}$ & $\begin{array}{l}20 \mathrm{Jan} \text { to } 18 \\
\text { Feb, } 2020\end{array}$ & Mean serial interval 7.5 days and SD 3.4 & NGMA & $5.8(0.6-11.0)$ \\
\hline
\end{tabular}




\begin{tabular}{|c|c|c|c|c|c|c|}
\hline & $\operatorname{Japan}^{\mathrm{a}}$ & & & & & \\
\hline 25 & $\begin{array}{l}\text { Kuniya, } 2020[39], \\
\text { Japan }^{\mathrm{a}}\end{array}$ & SEIR model & $\begin{array}{l}15 \text { Jan to } 29 \\
\text { Feb } 2020\end{array}$ & Infected increases at a rate of daily time increment & NGMA & $2.60(2.40-2.80)$ \\
\hline \multirow[b]{2}{*}{26} & \multirow{2}{*}{$\begin{array}{l}\text { Rocklov et al., } 2020 \text { [41], } \\
\text { Diamond Princess Cruise ship, } \\
\text { Japan }\end{array}$} & \multirow[b]{2}{*}{ SEIR model } & \multirow[b]{2}{*}{$\begin{array}{l}21 \text { Jan to } 19 \\
\text { Feb } 2020\end{array}$} & The individual can mix randomly & MCMC & 14.80 \\
\hline & & & & With isolation and quarantine intervention & $\mathrm{MCMC}$ & 1.78 \\
\hline 27 & $\begin{array}{l}\text { Iwata \& Miyakoshi, } 2020 \text { [53], } \\
\text { Outside of China }^{\mathrm{a}}\end{array}$ & SEIR model & NA & One infected entered a community of 1000 population. & MCMC & $6.5(5.6-7.2)$ \\
\hline 28 & $\begin{array}{l}\text { Wan et al., } 2020 \text { [37], } \\
\text { Wuhan, China }^{\mathrm{a}}\end{array}$ & SEIR model & $\begin{array}{l}22 \text { Jan to } 07 \\
\text { Feb } 2020\end{array}$ & $\begin{array}{l}7 \text { days incubation period and } 14 \text { days of the infectious } \\
\text { period }\end{array}$ & SEIR method & $1.44(1.40-1.47)$ \\
\hline 29 & $\begin{array}{l}\text { D'Arienzo \& Coniglio, } 2020 \\
\text { [46], } \\
\text { Italy }\end{array}$ & SIR model & $\begin{array}{l}25 \text { Feb to } 12 \\
\text { Mar } 2020\end{array}$ & Nearly everyone in Italy is susceptible & SEIR method & 3.10 \\
\hline \multirow[b]{4}{*}{30} & $\begin{array}{l}\text { Yuan et al., } 2020 \text { [47], } \\
\text { Italy }^{\mathrm{a}}\end{array}$ & \multirow[b]{4}{*}{$\begin{array}{l}\text { No model } \\
\text { mentioned }\end{array}$} & \multirow[b]{4}{*}{$\begin{array}{l}23 \mathrm{Feb} \text { to } 9 \\
\text { Mar } 2020\end{array}$} & \multirow[b]{4}{*}{ Mean generation time 5.6 days and SD 2.6 days } & \multirow[b]{4}{*}{ EGR } & $3.27(3.17-3.38)$ \\
\hline & $\begin{array}{l}\text { Yuan et al., } 2020[47], \\
\text { France }^{\mathrm{a}}\end{array}$ & & & & & $6.32(5.72-6.99)$ \\
\hline & $\begin{array}{l}\text { Yuan et al., } 2020[47], \\
\text { Germany }^{\mathrm{a}}\end{array}$ & & & & & $6.07(5.51-6.69)$ \\
\hline & $\begin{array}{l}\text { Yuan et al., } 2020[47], \\
\text { Spain }^{\mathrm{a}}\end{array}$ & & & & & $5.08(4.51-5.74)$ \\
\hline
\end{tabular}

Note: a: studies included in meta-analysis, b: studies described narratively. ${ }^{1}$ EGR: Exponential growth rate method; MLE: Maximum Likelihood method; MCMC: Markov Chain Monte Carlo method; NGMA: Next-generation matrix approach and SEIR method $=\beta / \gamma$ method. R: Reproductive number, 95\% CI, 95\% Confidence Interval ${ }^{2}$ Serial interval refers to the duration of time between the onset of symptoms in an index case and a secondary case
${ }^{3}$ Generation
time
refers
to the
time
interval
between
successive
infections
in
the
chain
of
transmission 
medRxiv preprint doi: https://doi.org/10.1101/2020.05.23.20111021; this version posted May 31, 2020. The copyright holder for this preprint (which was not certified by peer review) is the author/funder, who has granted medRxiv a license to display the preprint in perpetuity.

It is made available under a CC-BY-NC 4.0 International license .

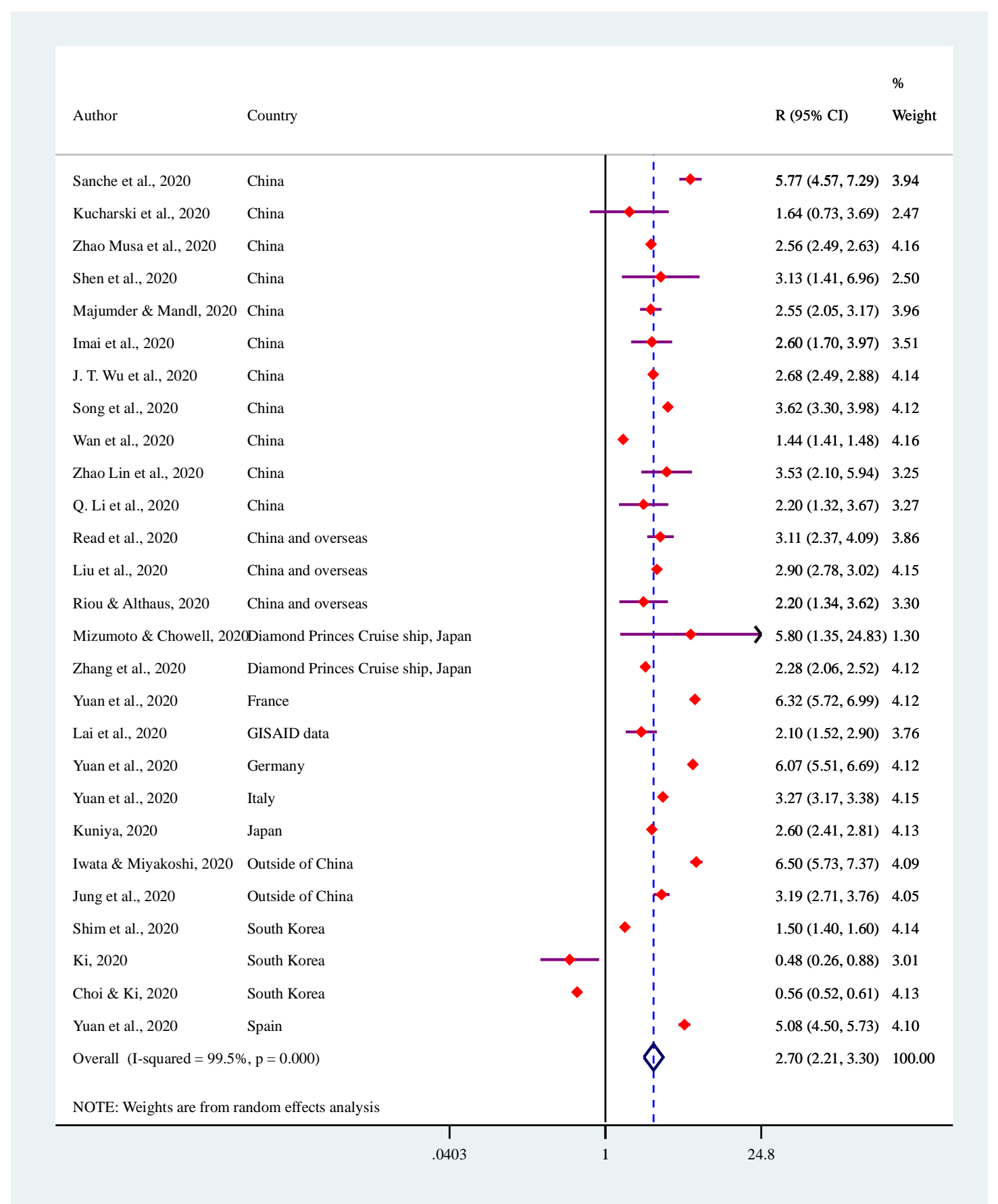

Figure 3: Summarized reproductive number of COVID-19 (total 24 studies with 27 times report of COVID-19's reproductive number [one study (Yuan et al., 2020) reported estimates for four different countries]) 
Table 2: Sources of heterogeneity of the estimated COVID-19's reproductive number

\begin{tabular}{|c|c|c|c|c|}
\hline \multirow[t]{2}{*}{ Characteristics } & \multirow{2}{*}{$\begin{array}{l}\text { Number } \\
\text { of } \\
\text { studies }^{* *}\end{array}$} & \multirow[t]{2}{*}{ R $(95 \%$ CI $)$} & \multicolumn{2}{|c|}{$\mathbf{P}$} \\
\hline & & & Heterogeneity & $\begin{array}{l}\text { Meta- } \\
\text { regression }\end{array}$ \\
\hline \multicolumn{5}{|l|}{ Country } \\
\hline China & 11 & $2.72(2.08-3.57)$ & $<0.01$ & $<0.01$ \\
\hline China and overseas & 3 & $2.90(2.78-3.02)$ & 0.490 & \\
\hline Outside of China & 2 & $4.56(2.28-9.12)$ & $<0.01$ & \\
\hline Japan & 1 & $2.60(2.41-2.81)$ & NA & \\
\hline $\begin{array}{l}\text { Diamond Princes Cruise } \\
\text { ship, Japan }\end{array}$ & 2 & $2.71(1.33-5.26)$ & 0.290 & \\
\hline South Korea & 3 & $0.76(0.34-1.70)$ & $<0.01$ & \\
\hline Italy & 1 & $3.27(3.16-3.38)$ & NA & \\
\hline Germany & 1 & $6.07(5.51-6.69)$ & NA & \\
\hline Spain & 1 & $5.08(4.50-5.73)$ & NA & \\
\hline France & 1 & $6.32(5.72-6.98)$ & NA & \\
\hline $\begin{array}{l}\text { Global Initiative on Sharing } \\
\text { Al Influenza Data }\end{array}$ & 1 & $2.1(1.52-2.90)$ & NA & \\
\hline \multicolumn{5}{|l|}{ Method considered } \\
\hline MLE & 4 & $2.63(2.17-3.18)$ & $<0.01$ & $<0.05$ \\
\hline EGR & 6 & $3.67(2.90-4.64)$ & $<0.01$ & \\
\hline SEIR & 4 & $1.67(0.82-3.38)$ & $<0.01$ & \\
\hline MCMC & 2 & $4.18(1.75-9.93)$ & $<0.01$ & \\
\hline NGMA & 2 & $2.76(1.82-4.16)$ & 0.280 & \\
\hline Others & 6 & $2.11(1.60-2.79)$ & $<0.01$ & \\
\hline \multicolumn{5}{|l|}{ Model considered } \\
\hline SEIR model & 10 & $2.57(1.69-3.92)$ & $<0.01$ & 0.9470 \\
\hline SIR model & 1 & $2.55(2.05-3.18)$ & NA & \\
\hline Epidemic curve & 13 & $2.86(2.39-3.42)$ & $<0.01$ & \\
\hline \multicolumn{5}{|l|}{ Number of cases } \\
\hline$\leq 3162$ & 16 & $2.50(1.91-3.28)$ & $<0.01$ & 0.7881 \\
\hline$>3162$ & 11 & $2.97(2.09-4.23)$ & $<0.01$ & \\
\hline
\end{tabular}


Note: ** Number of studies 24 with reproductive number record 27 time (one study reported estimate for four different countries)

The results of the narrative synthesis are presented in Table 3. Total of six studies were narratively synthesized. The findings of these six studies also supported our summary estimate. A study conducted for Diamond Princes Cruise Ship, Japan found reproductive number of COVID-19 was 14.8 for the period of 21 January to 19 February 2020 [41]. However, this estimated reproductive number was conditioned for not to applied any preventive intervention and infected person can mix randomly to the non-infected persons. When preventive interventions applied this number was reduced to 1.78 . 
Table 3: Narrative synthesis of the studies included in in review

\begin{tabular}{|c|c|c|c|c|}
\hline $\begin{array}{l}\text { Author, } \\
\text { Study's Location }\end{array}$ & Model & Time/period & Assumptions and method & Results \\
\hline $\begin{array}{l}\text { T. Zhou et al, } 2020 \text { [18], } \\
\text { China }^{b}\end{array}$ & SEIR model & $\begin{array}{l}\text { before 26th Jan } \\
2020\end{array}$ & $\begin{array}{l}\text { With time generation of } 8.4 \text { and } 10 \text { days } \\
\text { and using the exponential growth rate } \\
\text { method }\end{array}$ & $\begin{array}{l}\text { Estimated basic reproductive number was } \\
\text { varied from } 2.83 \text { to } 3.34 \text { (for } 8.4 \text { days } \\
\text { generation time) or } 3.28 \text { to } 3.93 \text { (for } 10 \text { days } \\
\text { generation time). }\end{array}$ \\
\hline $\begin{array}{l}\text { Tang et al., } 2020 \text { [29], } \\
\text { China }^{b}\end{array}$ & $\begin{array}{l}\text { SEIR model (with } \\
\text { isolation, quarantined) }\end{array}$ & $\begin{array}{l}31 \text { Dec } 2019 \text { to } \\
\text { 15th Jan } 2020\end{array}$ & $\begin{array}{l}\text { The incubation period was } 7 \text { days, } \\
\text { ignoring the asymptomatic infection in the } \\
\text { model and using the next generation } \\
\text { matrix approach }\end{array}$ & $\begin{array}{l}\text { The estimated reproductive number was } 6.47 \\
\text { (5.71-7.23) during the control measures of } \\
\text { isolation and quarantine are implementing. }\end{array}$ \\
\hline $\begin{array}{l}\text { T.-M. Chen et al., } 2020 \text { [33], } \\
\text { Wuhan, China }^{\text {b }}\end{array}$ & $\begin{array}{l}\text { SEIR (Bat-Host- } \\
\text { Reservoir-People } \\
\text { network model) }\end{array}$ & $\begin{array}{l}10^{\text {th }} \text { Jan to } 24^{\text {th }} \text { Jan } \\
2020\end{array}$ & $\begin{array}{l}\text { Assuming the mean incubation 5.2, mean } \\
\text { infectious period } 5.8 \text { and using the next } \\
\text { generation matrix approach }\end{array}$ & $\begin{array}{l}\text { The basic reproduction number estimated was } \\
2.30 \text { from reservoir to person. It was } \\
\text { increased to } 3.58 \text { when reached person-to- } \\
\text { person level transmission. }\end{array}$ \\
\hline $\begin{array}{l}\text { W. Zhou et al., } 2020 \text { [32], } \\
\text { China }^{\text {b }}\end{array}$ & $\begin{array}{l}\text { SEIHR model } \\
\text { extended by } \\
\text { quarantined }\end{array}$ & before 10 Jan 2020 & $\begin{array}{l}\text { Parameterizing cumulative cases, deaths, } \\
\text { daily number of media reports and } \\
\text { proportion of quarantined exposed by the } \\
\text { virus and the estimation method was next } \\
\text { generation matrix approach }\end{array}$ & The basic reproductive number was 5.32 . \\
\hline $\begin{array}{l}\text { Rocklov et al., } 2020 \text { [41], } \\
\text { Diamond Princess Cruise } \\
\text { ship, Japan }^{\text {b }}\end{array}$ & SEIR model & $\begin{array}{l}21 \text { Jan to } 19 \text { Feb } \\
2020\end{array}$ & $\begin{array}{l}\text { The individual can mix randomly, } \\
\text { infectious period was } 10 \text { days and contact } \\
\text { rate was same as early outbreak using the } \\
\text { SEIR method. }\end{array}$ & $\begin{array}{l}\text { The basic reproductive number was } 14.80 \\
\text { without any intervention by using } 79 \% \\
\text { infected persons in the ship. However, } \\
\text { isolation and quarantine before } 62.35 \% \\
\text { infected cases reduce this number to } 1.78 \text {. }\end{array}$ \\
\hline $\begin{array}{l}\text { D’Arienzo \& Coniglio, } 2020 \\
{[46] \text {, }} \\
\text { Italy }^{\mathrm{b}}\end{array}$ & SIR model & $\begin{array}{l}25 \text { Feb to } 12 \text { Mar } \\
2020\end{array}$ & $\begin{array}{l}\text { Nearly everyone in Italy were considered } \\
\text { as susceptible using the general SEIR } \\
\text { method }\end{array}$ & $\begin{array}{l}\text { The Ro was } 3.10 \text { while the number varies } \\
\text { from } 2.46 \text { to } 3.09 \text { in different region across } \\
\text { Italy. }\end{array}$ \\
\hline
\end{tabular}


medRxiv preprint doi: https://doi.org/10.1101/2020.05.23.20111021; this version posted May 31, 2020. The copyright holder for this preprint (which was not certified by peer review) is the author/funder, who has granted medRxiv a license to display the preprint in perpetuity.

It is made available under a CC-BY-NC 4.0 International license .

\section{Discussion}

This review aimed to provide the reproductive number of COVID-19 based on the global level evidence. A total of 30 studies selected for this study of which 24 studies were included in the meta-analysis. Majority of the included studies were conducted in China. The average estimated reproductive number was 2.70 with evidence of higher heterogeneity across the included studies. The sources of heterogeneity were countries for which the reproductive number estimated, models and methods used to estimate the reproductive number, and the number of cases used to estimate the reproductive number.

The average estimated reproductive number was 2.7; which is higher than the WHO's estimate of 1.4 to 2.5 . However, this estimate is lower than the previous summarized reproductive number of COVID-19 (3.28) [54]. Numerous measures to reduce new infections of COVID-19 such as social distancing, and controlling international travels are associated with such reduction $[17,55]$. However, our estimated reproductive number is still very high that leads an exponential increase of new infections. Moreover, the estimated number is still very higher than previous rounds of COVID-19's like infectious diseases, such as SARS and MERS if we considered time period between the when was estimation done and infections was initially detected. For instance, the reproductive number of SARS and MERS were reduced to 0.95 (95\% CI, 0.61-1,23) and 0.91 (95\% CI, 0.36-1.44) after $3^{\text {rd }}$ generation of the infection [56]. There are numerous reasons for such a higher reproductive number. First, biological facts of the infection rate and duration of contagion are important to explain such higher reproductive number instead of strict control measures that placed to reduce new infections [57]. For instance, a person could be infected in numerous ways, such as gets physically contacted with the infected person or through environmental transmission by respiratory droplets [58]. Moreover, COVID-19 infected patients may not show symptomatic characteristics up to two weeks of infection. This pre-symptomatic stage is another source to increase new infections exponentially as in this period an infected 
medRxiv preprint doi: https://doi.org/10.1101/2020.05.23.20111021; this version posted May 31, 2020. The copyright holder for this preprint

(which was not certified by peer review) is the author/funder, who has granted medRxiv a license to display the preprint in perpetuity.

It is made available under a CC-BY-NC 4.0 International license .

person is usually confounded in the community with other people. This risk is further increased significantly for the country where population density is high [59].

This study also found evidence of the very high $(99.5 \%)$ heterogeneity of the estimated reproductive number. Along with the factors described above, characteristics used to estimate reproductive numbers are important source for such heterogeneity. For instance, the reproductive number found higher for the countries where no restriction was applied or restriction was applied in delayed. The forms of restrictions were control people's movement, personal hygiene, and wearing mask $[10,60]$. These implications act to control virus transmission from an infected to the susceptible and reduce the new infections. These also affect the average transmissibility of COVID-19 within the specific population and settings [61,62].

Estimation models, assumptions applied, and estimation processes were empirical sources of variability of the estimated COVID-19's reproductive number [63]. For instance, studies included in this analysis were followed assumption of generation time (which is followed by the gamma distribution) or serial interval (which is followed by the poison distribution) which is an important source of heterogeneity [64-66]. The reason of such difference is the underlying concept: generation time refers to the average time between transmission the virus from an infected person to the non-infected person whereas serial interval refers duration between onset of symptoms in an index case to the transmission in a secondary case $[64,65,67]$. Moreover, the estimated reproduction number generated by mathematical models is dependent on numerous decisions made by the researcher such as homogeneity or heterogeneity of the population considered; use a deterministic or stochastic approach and which distributions to be used to describe the probable values of parameters [57]. 
This study was first of its kind that provides an estimation of reproductive numbers based on worldwide' literature. Moreover, we have considered the heterogeneity of the reproductive numbers estimated worldwide and explored the sources of heterogeneity across selected studies' characteristics. However, many other factors may explain the sources of heterogeneity of the reported reproductive number of COVID-19 worldwide. We did not explore these because of the lack of data.

\section{Conclusion}

The average estimated reproductive number was 2.70 . We found evidence of higher heterogeneity of the reproductive number reported worldwide. There are numerous causes of such heterogeneity, however, study related characteristics were countries for which the reproductive number estimated, methods and models used to estimate reproductive number, and the number of cases considered to estimate reproductive number. This analysis indicates possibility to significant increase of COVID-19 infections in the coming days. Strengthing existing preventive measures as well as new policies and programs are important to reduce new infections.

\section{Acknowledgment}

The authors are grateful to the authors of the paper included in this review.

\section{Conflict of interest}

There is no conflict of interest.

\section{Funds}

This study did not received any financial support.

\section{Ethical approval}

Ethical approval was not necessary for this kind of study. 
medRxiv preprint doi: https://doi.org/10.1101/2020.05.23.20111021; this version posted May 31, 2020. The copyright holder for this preprint (which was not certified by peer review) is the author/funder, who has granted medRxiv a license to display the preprint in perpetuity. It is made available under a CC-BY-NC 4.0 International license .

\section{References}

1. Coronavirus Update (Live) - Worldometer. In: Worldometer [Internet]. [cited 22 May 2020]. Available: https://www.worldometers.info/coronavirus/

2. WHO. Novel Coronavirus(2019-nCoV) Situation Report - 10. World Health Organization; 2020 Jan p. 7. Report No.: 10. Available: https://www.who.int/docs/defaultsource/coronaviruse/situation-reports/20200130-sitrep-10-ncov.pdf?sfvrsn=d0b2e480_2

3. Mohamed AA, Mohamed N, Mohamoud S, Zahran FE, Khattab RA, El-Damasy DA, et al. SARS-CoV-2: The Path of Prevention and Control. Infect Disord - Drug Targets. 2020;20. doi:10.2174/1871526520666200520112848

4. Chen N, Zhou M, Dong X, Qu J, Gong F, Han Y, et al. Epidemiological and clinical characteristics of 99 cases of 2019 novel coronavirus pneumonia in Wuhan, China: a descriptive study. The Lancet. 2020;395: 507-513. doi:10.1016/S0140-6736(20)30211-7

5. Chen X, Yu B. First two months of the 2019 Coronavirus Disease (COVID-19) epidemic in China: real-time surveillance and evaluation with a second derivative model. Glob Health Res Policy. 2020;5: 7. doi:10.1186/s41256-020-00137-4

6. Kahn JS, McIntosh K. History and Recent Advances in Coronavirus Discovery: Pediatr Infect Dis J. 2005;24: S223-S227. doi:10.1097/01.inf.0000188166.17324.60

7. Zhong NS, Zheng BJ, Li YM, Poon null, Xie ZH, Chan KH, et al. Epidemiology and cause of severe acute respiratory syndrome (SARS) in Guangdong, People's Republic of China, in February, 2003. Lancet Lond Engl. 2003;362: 1353-1358. doi:10.1016/s01406736(03)14630-2

8. Zaki AM, van Boheemen S, Bestebroer TM, Osterhaus ADME, Fouchier RAM. Isolation of a Novel Coronavirus from a Man with Pneumonia in Saudi Arabia. N Engl J Med. 2012;367: 1814-1820. doi:10.1056/NEJMoa1211721

9. Cowling BJ, Park M, Fang VJ, Wu P, Leung GM, Wu JT. Preliminary epidemiological assessment of MERS-CoV outbreak in South Korea, May to June 2015. Euro Surveill Bull Eur Sur Mal Transm Eur Commun Dis Bull. 2015;20: 7-13. doi:10.2807/15607917.es2015.20.25.21163

10. Adhikari SP, Meng S, Wu Y-J, Mao Y-P, Ye R-X, Wang Q-Z, et al. Epidemiology, causes, clinical manifestation and diagnosis, prevention and control of coronavirus disease (COVID19) during the early outbreak period: a scoping review. Infect Dis Poverty. 2020;9. doi:10.1186/s40249-020-00646-x

11. Jiang $\mathrm{S}, \mathrm{Du} \mathrm{L}$, Shi $\mathrm{Z}$. An emerging coronavirus causing pneumonia outbreak in Wuhan, China: calling for developing therapeutic and prophylactic strategies. Emerg Microbes Infect. 2020;9: 275-277. doi:10.1080/22221751.2020.1723441

12. Chan JF-W, Yuan S, Kok K-H, To KK-W, Chu H, Yang J, et al. A familial cluster of pneumonia associated with the 2019 novel coronavirus indicating person-to-person transmission: a study of a family cluster. The Lancet. 2020;395: 514-523. doi:10.1016/S0140-6736(20)30154-9 
medRxiv preprint doi: https://doi.org/10.1101/2020.05.23.20111021; this version posted May 31, 2020. The copyright holder for this preprint (which was not certified by peer review) is the author/funder, who has granted medRxiv a license to display the preprint in perpetuity. It is made available under a CC-BY-NC 4.0 International license .

13. Wang D, Hu B, Hu C, Zhu F, Liu X, Zhang J, et al. Clinical Characteristics of 138 Hospitalized Patients With 2019 Novel Coronavirus-Infected Pneumonia in Wuhan, China. JAMA. 2020;323: 1061. doi:10.1001/jama.2020.1585

14. Wu F, Zhao S, Yu B, Chen Y-M, Wang W, Song Z-G, et al. A new coronavirus associated with human respiratory disease in China. Nature. 2020;579: 265-269. doi:10.1038/s41586020-2008-3

15. Wu P, Hao X, Lau EHY, Wong JY, Leung KSM, Wu JT, et al. Real-time tentative assessment of the epidemiological characteristics of novel coronavirus infections in Wuhan, China, as at 22 January 2020. Eurosurveillance. 2020;25. doi:10.2807/15607917.ES.2020.25.3.2000044

16. $\mathrm{Wu} \mathrm{Z}, \mathrm{McGoogan} \mathrm{JM}$. Characteristics of and Important Lessons From the Coronavirus Disease 2019 (COVID-19) Outbreak in China: Summary of a Report of 72314 Cases From the Chinese Center for Disease Control and Prevention. JAMA. 2020 [cited 18 Mar 2020]. doi:10.1001/jama.2020.2648

17. Zhong P, Guo S, Chen T. Correlation between travellers departing from Wuhan before the Spring Festival and subsequent spread of COVID-19 to all provinces in China. J Travel Med. 2020;27. doi:10.1093/jtm/taaa036

18. Zhou T, Liu Q, Yang Z, Liao J, Yang K, Bai W, et al. Preliminary prediction of the basic reproduction number of the Wuhan novel coronavirus 2019 $\square \mathrm{nCoV}$. J Evid-Based Med. 2020;13: 3-7. doi:10.1111/jebm.12376

19. Riou J, Althaus CL. Pattern of early human-to-human transmission of Wuhan 2019 novel coronavirus (2019-nCoV), December 2019 to January 2020. Eurosurveillance. 2020;25. doi:10.2807/1560-7917.ES.2020.25.4.2000058

20. Heesterbeek JAP, Roberts MG. The type-reproduction number $\mathrm{T}$ in models for infectious disease control. Math Biosci. 2007;206: 3-10. doi:10.1016/j.mbs.2004.10.013

21. Swerdlow DL, Finelli L. Preparation for Possible Sustained Transmission of 2019 Novel Coronavirus: Lessons From Previous Epidemics. JAMA. 2020 [cited 18 Mar 2020]. doi:10.1001/jama.2020.1960

22. Heffernan JM, Smith RJ, Wahl LM. Perspectives on the basic reproductive ratio. J R Soc Interface. 2005;2: 281-293. doi:10.1098/rsif.2005.0042

23. Woolhouse M. Quantifying Transmission. In: Baquero F, Bouza E, Gutiérrez-Fuentes JA, Coque TM, editors. Microbial Transmission. Washington, DC, USA: ASM Press; 2019. pp. 279-289. doi:10.1128/9781555819743.ch16

24. Li MY. An Introduction to Mathematical Modeling of Infectious Diseases. Cham: Springer International Publishing; 2018. doi:10.1007/978-3-319-72122-4

25. Vynnycky E, White RG. An introduction to infectious disease modelling. New York: Oxford University Press; 2010.

26. Imai N, Cori A, Dorigatti I, Baguelin M, Donnelly CA, Riley S. Report 3: Transmissibility of 2019-nCoV. 2020; 5. 
medRxiv preprint doi: https://doi.org/10.1101/2020.05.23.20111021; this version posted May 31, 2020. The copyright holder for this preprint

(which was not certified by peer review) is the author/funder, who has granted medRxiv a license to display the preprint in perpetuity.

It is made available under a CC-BY-NC 4.0 International license .

27. Sanche S, Lin YT, Xu C, Romero-Severson E, Hengartner N, Ke R. High Contagiousness and Rapid Spread of Severe Acute Respiratory Syndrome Coronavirus 2. Emerg Infect Dis. 2020;26. doi:10.3201/eid2607.200282

28. Song QQ, Zhao H, Fang LQ, Liu W, Zheng C, Zhang Y. Study on assessing early epidemiological parameters of COVID-19 epidemic in China. Zhonghua Liu Xing Bing Xue Za Zhi Zhonghua Liuxingbingxue Zazhi. 2020;41: 461-465. doi:10.3760/cma.j.cn11233820200205-00069

29. Tang B, Wang X, Li Q, Bragazzi NL, Tang S, Xiao Y, et al. Estimation of the Transmission Risk of the 2019-nCoV and Its Implication for Public Health Interventions. J Clin Med. 2020;9: 462. doi:10.3390/jcm9020462

30. Zhao S, Lin Q, Ran J, Musa SS, Yang G, Wang W, et al. Preliminary estimation of the basic reproduction number of novel coronavirus (2019-nCoV) in China, from 2019 to 2020: A data-driven analysis in the early phase of the outbreak. Int J Infect Dis. 2020;92: 214-217. doi:10.1016/j.ijid.2020.01.050

31. Zhao S, Musa SS, Lin Q, Ran J, Yang G, Wang W, et al. Estimating the Unreported Number of Novel Coronavirus (2019-nCoV) Cases in China in the First Half of January 2020: A Data-Driven Modelling Analysis of the Early Outbreak. J Clin Med. 2020;9: 388. doi: $10.3390 / \mathrm{jcm} 9020388$

32. Zhou W, Wang A, Xia F, Xiao Y, Tang S. Effects of media reporting on mitigating spread of COVID-19 in the early phase of the outbreak. Math Biosci Eng. 2020;17: 2693-2707. doi:10.3934/mbe.2020147

33. Chen T-M, Rui J, Wang Q-P, Zhao Z-Y, Cui J-A, Yin L. A mathematical model for simulating the phase-based transmissibility of a novel coronavirus. Infect Dis Poverty. 2020;9: 24. doi:10.1186/s40249-020-00640-3

34. Li Q, Guan X, Wu P, Wang X, Zhou L, Tong Y, et al. Early Transmission Dynamics in Wuhan, China, of Novel Coronavirus-Infected Pneumonia. N Engl J Med. 2020; NEJMoa2001316. doi:10.1056/NEJMoa2001316

35. Majumder M, Mandl KD. Early Transmissibility Assessment of a Novel Coronavirus in Wuhan, China. SSRN Electron J. 2020 [cited 12 May 2020]. doi:10.2139/ssrn.3524675

36. Shen M, Peng Z, Xiao Y, Zhang L. Modelling the epidemic trend of the 2019 novel coronavirus outbreak in China. Microbiology; 2020 Jan. doi:10.1101/2020.01.23.916726

37. Wan K, Chen J, Lu C, Dong L, Wu Z, Zhang L. When will the battle against novel coronavirus end in Wuhan: A SEIR modeling analysis. J Glob Health. 2020;10: 011002. doi:10.7189/jogh.10.011002

38. Wu JT, Leung K, Leung GM. Nowcasting and forecasting the potential domestic and international spread of the 2019-nCoV outbreak originating in Wuhan, China: a modelling study. The Lancet. 2020;395: 689-697. doi:10.1016/S0140-6736(20)30260-9

39. Kuniya T. Prediction of the Epidemic Peak of Coronavirus Disease in Japan, 2020. J Clin Med. 2020;9: 789. doi:10.3390/jcm9030789 
medRxiv preprint doi: https://doi.org/10.1101/2020.05.23.20111021; this version posted May 31, 2020. The copyright holder for this preprint

(which was not certified by peer review) is the author/funder, who has granted medRxiv a license to display the preprint in perpetuity.

It is made available under a CC-BY-NC 4.0 International license .

40. Mizumoto K, Chowell G. Transmission potential of the novel coronavirus (COVID-19) onboard the diamond Princess Cruises Ship, 2020. Infect Dis Model. 2020;5: 264-270. doi:10.1016/j.idm.2020.02.003

41. Rocklöv J, Sjödin H, Wilder-Smith A. COVID-19 outbreak on the Diamond Princess cruise ship: estimating the epidemic potential and effectiveness of public health countermeasures. J Travel Med. 2020; taaa030. doi:10.1093/jtm/taaa030

42. Zhang S, Diao M, Yu W, Pei L, Lin Z, Chen D. Estimation of the reproductive number of novel coronavirus (COVID-19) and the probable outbreak size on the Diamond Princess cruise ship: A data-driven analysis. Int $J$ Infect Dis. 2020;93: 201-204. doi:10.1016/j.ijid.2020.02.033

43. Choi S, Ki M. Estimating the reproductive number and the outbreak size of COVID-19 in Korea. Epidemiol Health. 2020;42: e2020011. doi:10.4178/epih.e2020011

44. Ki M. Epidemiologic characteristics of early cases with 2019 novel coronavirus (2019nCoV) disease in Korea. Epidemiol Health. 2020;42: e2020007. doi:10.4178/epih.e2020007

45. Shim E, Tariq A, Choi W, Lee Y, Chowell G. Transmission potential and severity of COVID-19 in South Korea. Int J Infect Dis. 2020;93: 339-344. doi:10.1016/j.ijid.2020.03.031

46. D'Arienzo M, Coniglio A. Assessment of the SARS-CoV-2 basic reproduction number, R0, based on the early phase of COVID-19 outbreak in Italy. Biosaf Health. 2020; S2590053620300410. doi:10.1016/j.bsheal.2020.03.004

47. Yuan J, Li M, Lv G, Lu ZK. Monitoring Transmissibility and Mortality of COVID-19 in Europe. Int J Infect Dis. 2020 [cited 11 May 2020]. doi:10.1016/j.ijid.2020.03.050

48. Kucharski AJ, Russell TW, Diamond C, Liu Y, Edmunds J, Funk S, et al. Early dynamics of transmission and control of COVID-19: a mathematical modelling study. Lancet Infect Dis. 2020; S1473309920301444. doi:10.1016/S1473-3099(20)30144-4

49. Liu T, Hu J, Xiao J, He G, Kang M, Rong Z, et al. Time-varying transmission dynamics of Novel Coronavirus Pneumonia in China. Systems Biology; 2020 Jan. doi:10.1101/2020.01.25.919787

50. Read JM, Bridgen JR, Cummings DA, Ho A, Jewell CP. Novel coronavirus 2019-nCoV: early estimation of epidemiological parameters and epidemic predictions. Infectious Diseases (except HIV/AIDS); 2020 Jan. doi:10.1101/2020.01.23.20018549

51. Lai A, Bergna A, Acciarri C, Galli M, Zehender G. Early phylogenetic estimate of the effective reproduction number of SARS $\square$ CoV $\square$ 2. J Med Virol. 2020;92: 675-679. doi:10.1002/jmv. 25723

52. Jung S, Akhmetzhanov AR, Hayashi K, Linton NM, Yang Y, Yuan B, et al. Real-Time Estimation of the Risk of Death from Novel Coronavirus (COVID-19) Infection: Inference Using Exported Cases. J Clin Med. 2020;9: 523. doi:10.3390/jcm9020523 
medRxiv preprint doi: https://doi.org/10.1101/2020.05.23.20111021; this version posted May 31, 2020. The copyright holder for this preprint

(which was not certified by peer review) is the author/funder, who has granted medRxiv a license to display the preprint in perpetuity.

It is made available under a CC-BY-NC 4.0 International license .

53. Iwata K, Miyakoshi C. A Simulation on Potential Secondary Spread of Novel Coronavirus in an Exported Country Using a Stochastic Epidemic SEIR Model. J Clin Med. 2020;9: 944. doi: $10.3390 / \mathrm{jcm} 9040944$

54. Liu Y, Gayle AA, Wilder-Smith A, Rocklöv J. The reproductive number of COVID-19 is higher compared to SARS coronavirus. J Travel Med. 2020;27: taaa021. doi:10.1093/jtm/taaa021

55. Chen $\mathrm{H}, \mathrm{Xu} \mathrm{W}$, Paris $\mathrm{C}$, Reeson A, Li X. Social distance and SARS memory: impact on the public awareness of 2019 novel coronavirus (COVID-19) outbreak. Infectious Diseases (except HIV/AIDS); 2020 Mar. doi:10.1101/2020.03.11.20033688

56. Chowell G, Abdirizak F, Lee S, Lee J, Jung E, Nishiura H, et al. Transmission characteristics of MERS and SARS in the healthcare setting: a comparative study. BMC Med. 2015;13: 112. doi:10.1186/s12916-015-0450-0

57. Delamater PL, Street EJ, Leslie TF, Yang YT, Jacobsen KH. Complexity of the Basic Reproduction Number (R0). Emerg Infect Dis. 2019;25: 1-4. doi:10.3201/eid2501.171901

58. , for the Zhongnan Hospital of Wuhan University Novel Coronavirus Management and Research Team, Evidence-Based Medicine Chapter of China International Exchange and Promotive Association for Medical and Health Care (CPAM), Jin Y-H, Cai L, Cheng Z-S, Cheng H, Deng T, et al. A rapid advice guideline for the diagnosis and treatment of 2019 novel coronavirus (2019-nCoV) infected pneumonia (standard version). Mil Med Res. 2020;7: 4. doi:10.1186/s40779-020-0233-6

59. Guerra FM, Bolotin S, Lim G, Heffernan J, Deeks SL, Li Y, et al. The basic reproduction number (R 0 ) of measles: a systematic review. Lancet Infect Dis. 2017;17: e420-e428. doi:10.1016/S1473-3099(17)30307-9

60. Cowling BJ, Ali ST, Ng TWY, Tsang TK, Li JCM, Fong MW, et al. Impact assessment of non-pharmaceutical interventions against COVID-19 and influenza in Hong Kong: an observational study. Epidemiology; 2020 Mar. doi:10.1101/2020.03.12.20034660

61. Lai S, Ruktanonchai NW, Zhou L, Prosper O, Luo W, Floyd JR, et al. Effect of nonpharmaceutical interventions for containing the COVID-19 outbreak in China. Infectious Diseases (except HIV/AIDS); 2020 Mar. doi:10.1101/2020.03.03.20029843

62. Imai N, Gaythorpe KAM, Abbott S, Bhatia S, van Elsland S, Prem K, et al. Adoption and impact of non-pharmaceutical interventions for COVID-19. Wellcome Open Res. 2020;5: 59. doi:10.12688/wellcomeopenres.15808.1

63. Huedo-Medina TB, Sánchez-Meca J, Marín-Martínez F, Botella J. Assessing heterogeneity in meta-analysis: Q statistic or I2 index? Psychol Methods. 2006;11: 193-206. doi:10.1037/1082-989X.11.2.193

64. Wallinga J, Lipsitch M. How generation intervals shape the relationship between growth rates and reproductive numbers. Proc R Soc B Biol Sci. 2007;274: 599-604. doi:10.1098/rspb.2006.3754

65. Svensson Å. A note on generation times in epidemic models. Math Biosci. 2007;208: 300311. doi:10.1016/j.mbs.2006.10.010 
medRxiv preprint doi: https://doi.org/10.1101/2020.05.23.20111021; this version posted May 31, 2020. The copyright holder for this preprint (which was not certified by peer review) is the author/funder, who has granted medRxiv a license to display the preprint in perpetuity.

It is made available under a CC-BY-NC 4.0 International license .

66. Vink MA, Bootsma MCJ, Wallinga J. Serial Intervals of Respiratory Infectious Diseases: A Systematic Review and Analysis. Am J Epidemiol. 2014;180: 865-875. doi:10.1093/aje/kwu209

67. Cowling BJ, Fang VJ, Riley S, Peiris JSM, Leung GM. Estimation of the serial interval of influenza. Epidemiol Camb Mass. 2009;20: 344-347. doi:10.1097/EDE.0b013e31819d1092 
medRxiv preprint doi: https://doi.org/10.1101/2020.05.23.20111021; this version posted May 31, 2020. The copyright holder for this preprint (which was not certified by peer review) is the author/funder, who has granted medRxiv a license to display the preprint in perpetuity.

It is made available under a CC-BY-NC 4.0 International license .

Reproductive number of COVID-19: A systematic review and meta-analysis based on global level evidence 
Supplemental Table 1. Web of science search results for pre-existing morbidities among COVID-19 patients

\begin{tabular}{|l|l|}
\hline Search terms & Results \\
\hline ((TS=(COVID-19 OR SARS-CoV-2 OR Coronavirus OR Corona Virus OR n2019-CoV OR novel coronavirus) AND \\
(Reproductive number)) AND LANGUAGE: (English) AND DOCUMENT TYPES: (Article) \\
Indexes=SCI-EXPANDED, SSCI, A\&HCI, CPCI-S, CPCI-SSH, BKCI-S, ESCI Timespan=2020
\end{tabular}

Supplemental Table 2. Science Direct search results for reproductive number of COVID-19

\begin{tabular}{|l|l|}
\hline Search strategy & Results \\
\hline ((COVID-19) OR (SARS-CoV-2) OR (Coronavirus) OR (Corona Virus) OR (n2019-CoV) OR (novel coronavirus)) \\
AND (Reproductive number) & 107 \\
Year(s): 2020, Article Types: Research article & \\
\hline
\end{tabular}

Supplemental Table 3. PUBMED search results for reproductive number of COVID-19

\begin{tabular}{|c|c|c|}
\hline $\begin{array}{l}\text { Search } \\
\text { number }\end{array}$ & Query & Results \\
\hline 5 & $\begin{array}{l}(((((((\text { Coronavirus) OR (Corona virus)) OR (COVID-19)) OR (SARS-CoV-2)) OR (n2019-CoV)) OR (novel } \\
\text { coronavirus)))) AND (Reproductive number)) AND (("2020/01/01"[Date - Publication] : "2020/04/15"[Date - } \\
\text { Publication])) AND (English[LANGUAGE]) }\end{array}$ & 79 \\
\hline 4 & ("2020/01/01"[Date - Publication] : "2020/04/15"[Date - Publication]) & 519,728 \\
\hline 3 & $\begin{array}{l}(((((\text { Coronavirus) OR (Corona virus)) OR (COVID-19)) OR (SARS-CoV-2)) OR (n2019-CoV)) OR (novel coronavirus)))) } \\
\text { AND (Reproductive number) }\end{array}$ & 243 \\
\hline 2 & Reproductive number & 135,860 \\
\hline 1 & $((((($ Coronavirus) OR (Corona virus)) OR (COVID-19)) OR (SARS-CoV-2)) OR (n2019-CoV)) OR (novel coronavirus))) & 33,736 \\
\hline
\end{tabular}


Supplemental Table 4. Assessment of the included study through the NIH assessment tool

\begin{tabular}{|c|c|c|c|c|c|c|c|c|c|c|}
\hline Author & 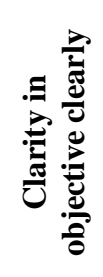 & 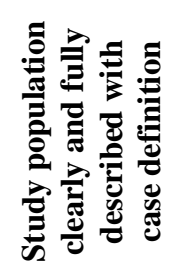 & 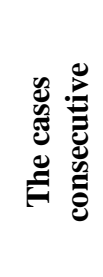 & 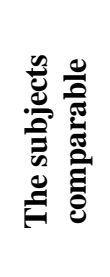 & 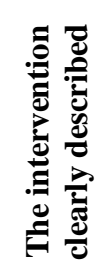 & 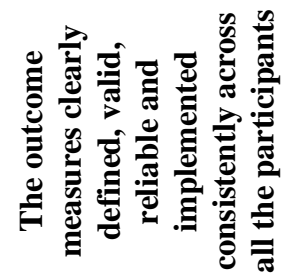 & 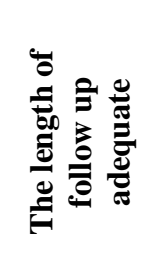 & 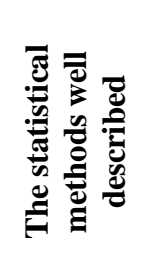 & 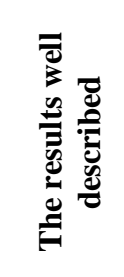 & Total score \\
\hline Read, et al & $\mathrm{Y}$ & $\mathrm{Y}$ & $\mathrm{Y}$ & $\mathrm{Y}$ & $\mathrm{Y}$ & $\mathrm{O}$ & $\mathrm{N}$ & $\mathrm{Y}$ & $\mathrm{Y}$ & 7 \\
\hline Zhou et al & $\mathrm{Y}$ & $\mathrm{Y}$ & $\mathrm{Y}$ & $\mathrm{Y}$ & $\mathrm{Y}$ & $\mathrm{Y}$ & $\mathrm{N}$ & $\mathrm{Y}$ & $\mathrm{Y}$ & 8 \\
\hline Zhang et al & $\mathrm{Y}$ & $\mathrm{Y}$ & $\mathrm{Y}$ & $\mathrm{Y}$ & $\mathrm{O}$ & $\mathrm{Y}$ & $\mathrm{N}$ & $\mathrm{Y}$ & $\mathrm{Y}$ & 7 \\
\hline Liu et al & $\mathrm{Y}$ & $\mathrm{Y}$ & $\mathrm{Y}$ & $\mathrm{O}$ & $\mathrm{Y}$ & $\mathrm{Y}$ & $\mathrm{Y}$ & $\mathrm{Y}$ & $\mathrm{Y}$ & 8 \\
\hline Majumder and Mandl & $\mathrm{N}$ & $\mathrm{Y}$ & $\mathrm{Y}$ & $\mathrm{Y}$ & $\mathrm{N}$ & $\mathrm{Y}$ & $\mathrm{N}$ & $\mathrm{Y}$ & $\mathrm{Y}$ & 6 \\
\hline Riou and Althaus & $\mathrm{Y}$ & $\mathrm{Y}$ & $\mathrm{Y}$ & $\mathrm{Y}$ & $\mathrm{N}$ & $\mathrm{Y}$ & $\mathrm{Y}$ & $\mathrm{Y}$ & $\mathrm{Y}$ & 8 \\
\hline Tang et al. & $\mathrm{Y}$ & $\mathrm{Y}$ & $\mathrm{Y}$ & $\mathrm{Y}$ & $\mathrm{Y}$ & $\mathrm{Y}$ & $\mathrm{Y}$ & $\mathrm{Y}$ & $\mathrm{Y}$ & 9 \\
\hline Zhao et al. & $\mathrm{Y}$ & $\mathrm{Y}$ & $\mathrm{Y}$ & $\mathrm{Y}$ & $\mathrm{O}$ & $\mathrm{Y}$ & $\mathrm{N}$ & $\mathrm{Y}$ & $\mathrm{Y}$ & 7 \\
\hline Zhao et al & $\mathrm{Y}$ & $\mathrm{Y}$ & $\mathrm{Y}$ & $\mathrm{Y}$ & $\mathrm{N}$ & $\mathrm{Y}$ & $\mathrm{Y}$ & $\mathrm{Y}$ & $\mathrm{Y}$ & 8 \\
\hline Shen et al & Y & $\mathrm{Y}$ & $\mathrm{Y}$ & $\mathrm{Y}$ & $\mathrm{Y}$ & $\mathrm{Y}$ & $\mathrm{N}$ & $\mathrm{Y}$ & $\mathrm{Y}$ & 8 \\
\hline Li et al. & $\mathrm{Y}$ & $\mathrm{Y}$ & $\mathrm{Y}$ & $\mathrm{Y}$ & $\mathrm{N}$ & $\mathrm{Y}$ & $\mathrm{Y}$ & $\mathrm{Y}$ & $\mathrm{Y}$ & 8 \\
\hline Wu et al & $\mathrm{Y}$ & $\mathrm{Y}$ & $\mathrm{Y}$ & $\mathrm{Y}$ & $\mathrm{Y}$ & $\mathrm{Y}$ & $\mathrm{Y}$ & $\mathrm{Y}$ & $\mathrm{Y}$ & 9 \\
\hline Imai et al & $\mathrm{Y}$ & $\mathrm{Y}$ & $\mathrm{Y}$ & $\mathrm{Y}$ & $\mathrm{O}$ & $\mathrm{Y}$ & $\mathrm{N}$ & $\mathrm{Y}$ & $\mathrm{Y}$ & 7 \\
\hline Chen et al & $\mathrm{Y}$ & $\mathrm{Y}$ & $\mathrm{Y}$ & $\mathrm{Y}$ & $\mathrm{Y}$ & $\mathrm{Y}$ & $\mathrm{N}$ & $\mathrm{Y}$ & $\mathrm{Y}$ & 8 \\
\hline Kucharski et al. & $\mathrm{Y}$ & $\mathrm{Y}$ & $\mathrm{Y}$ & $\mathrm{Y}$ & $\mathrm{Y}$ & $\mathrm{Y}$ & $\mathrm{Y}$ & $\mathrm{Y}$ & $\mathrm{Y}$ & 9 \\
\hline Ki et al., & $\mathrm{Y}$ & $\mathrm{Y}$ & $\mathrm{Y}$ & $\mathrm{Y}$ & $\mathrm{Y}$ & $\mathrm{Y}$ & $\mathrm{Y}$ & $\mathrm{Y}$ & $\mathrm{Y}$ & 9 \\
\hline Choi and $\mathrm{Ki}$ & $\mathrm{Y}$ & $\mathrm{Y}$ & $\mathrm{Y}$ & $\mathrm{Y}$ & $\mathrm{Y}$ & $\mathrm{Y}$ & $\mathrm{Y}$ & $\mathrm{Y}$ & $\mathrm{Y}$ & 9 \\
\hline Shim et al & $\mathrm{Y}$ & $\mathrm{Y}$ & $\mathrm{Y}$ & $\mathrm{Y}$ & $\mathrm{Y}$ & $\mathrm{Y}$ & $\mathrm{N}$ & $\mathrm{Y}$ & $\mathrm{Y}$ & 8 \\
\hline Lai et al., & $\mathrm{Y}$ & $\mathrm{Y}$ & $\mathrm{Y}$ & $\mathrm{Y}$ & $\mathrm{Y}$ & $\mathrm{Y}$ & $\mathrm{Y}$ & $\mathrm{Y}$ & $\mathrm{Y}$ & 9 \\
\hline Jung et al & $\mathrm{Y}$ & $\mathrm{Y}$ & $\mathrm{Y}$ & $\mathrm{Y}$ & $\mathrm{Y}$ & $\mathrm{Y}$ & $\mathrm{Y}$ & $\mathrm{Y}$ & $\mathrm{Y}$ & 8 \\
\hline Zhou et al & $\mathrm{Y}$ & Y & $\mathrm{Y}$ & Y & $\mathrm{Y}$ & $\mathrm{Y}$ & $\mathrm{Y}$ & $\mathrm{Y}$ & Y & 9 \\
\hline
\end{tabular}




\begin{tabular}{|c|c|c|c|c|c|c|c|c|c|c|}
\hline Song, et al & $\mathrm{Y}$ & $\mathrm{Y}$ & $\mathrm{Y}$ & $\mathrm{Y}$ & $\mathrm{O}$ & $\mathrm{O}$ & $\mathrm{O}$ & $\mathrm{Y}$ & $\mathrm{Y}$ & 6 \\
\hline Sanche et al. & $\mathrm{Y}$ & $\mathrm{Y}$ & $\mathrm{Y}$ & $\mathrm{Y}$ & $\mathrm{N}$ & $\mathrm{Y}$ & $\mathrm{N}$ & $\mathrm{Y}$ & $\mathrm{Y}$ & 7 \\
\hline Mizumoto and Chowell & $\mathrm{Y}$ & $\mathrm{Y}$ & $\mathrm{Y}$ & $\mathrm{Y}$ & $\mathrm{Y}$ & $\mathrm{Y}$ & $\mathrm{Y}$ & $\mathrm{Y}$ & $\mathrm{Y}$ & 9 \\
\hline Kuniya & $\mathrm{Y}$ & $\mathrm{Y}$ & $\mathrm{O}$ & $\mathrm{Y}$ & $\mathrm{O}$ & $\mathrm{Y}$ & $\mathrm{N}$ & $\mathrm{Y}$ & $\mathrm{Y}$ & 6 \\
\hline Rocklov, et al & $\mathrm{Y}$ & $\mathrm{Y}$ & $\mathrm{Y}$ & $\mathrm{Y}$ & $\mathrm{Y}$ & $\mathrm{Y}$ & $\mathrm{Y}$ & $\mathrm{Y}$ & $\mathrm{Y}$ & 9 \\
\hline Iwata and Miyakoshi & $\mathrm{Y}$ & $\mathrm{Y}$ & $\mathrm{N}$ & $\mathrm{Y}$ & $\mathrm{N}$ & $\mathrm{Y}$ & $\mathrm{N}$ & $\mathrm{Y}$ & $\mathrm{Y}$ & 7 \\
\hline Wan et al & $\mathrm{Y}$ & $\mathrm{Y}$ & $\mathrm{Y}$ & $\mathrm{Y}$ & $\mathrm{O}$ & $\mathrm{Y}$ & $\mathrm{Y}$ & $\mathrm{Y}$ & $\mathrm{Y}$ & 8 \\
\hline D'Arienzo, Coniglio & $\mathrm{Y}$ & $\mathrm{Y}$ & $\mathrm{Y}$ & $\mathrm{Y}$ & $\mathrm{N}$ & $\mathrm{N}$ & $\mathrm{N}$ & $\mathrm{Y}$ & $\mathrm{Y}$ & 6 \\
\hline Yuan, et al. & $\mathrm{Y}$ & $\mathrm{Y}$ & $\mathrm{Y}$ & $\mathrm{Y}$ & $\mathrm{Y}$ & $\mathrm{Y}$ & $\mathrm{Y}$ & $\mathrm{Y}$ & $\mathrm{Y}$ & 9 \\
\hline
\end{tabular}


medRxiv preprint doi: https://doi.org/10.1101/2020.05.23.20111021; this version posted May 31, 2020. The copyright holder for this preprint (which was not certified by peer review) is the author/funder, who has granted medRxiv a license to display the preprint in perpetuity.

It is made available under a CC-BY-NC 4.0 International license .

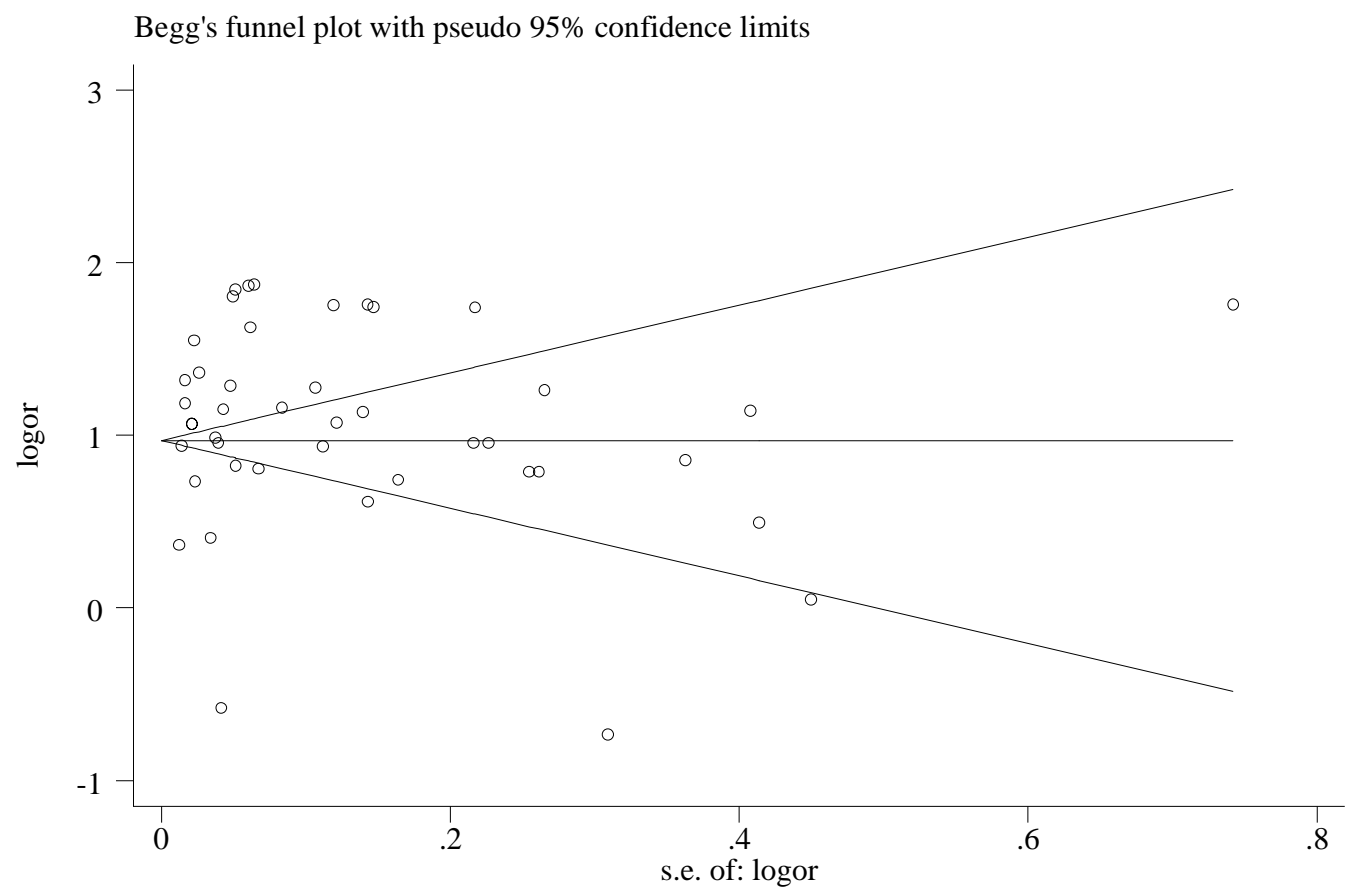

Supplementary Figure 1: Funnel plot for the included studies estimated reproductive number of COVID-19 to identify publication bias 
medRxiv preprint doi: https://doi.org/10.1101/2020.05.23.20111021; this version posted May 31, 2020. The copyright holder for this preprint (which was not certified by peer review) is the author/funder, who has granted medRxiv a license to display the preprint in perpetuity.

\section{It is made available under a CC-BY-NC 4.0 International license .}

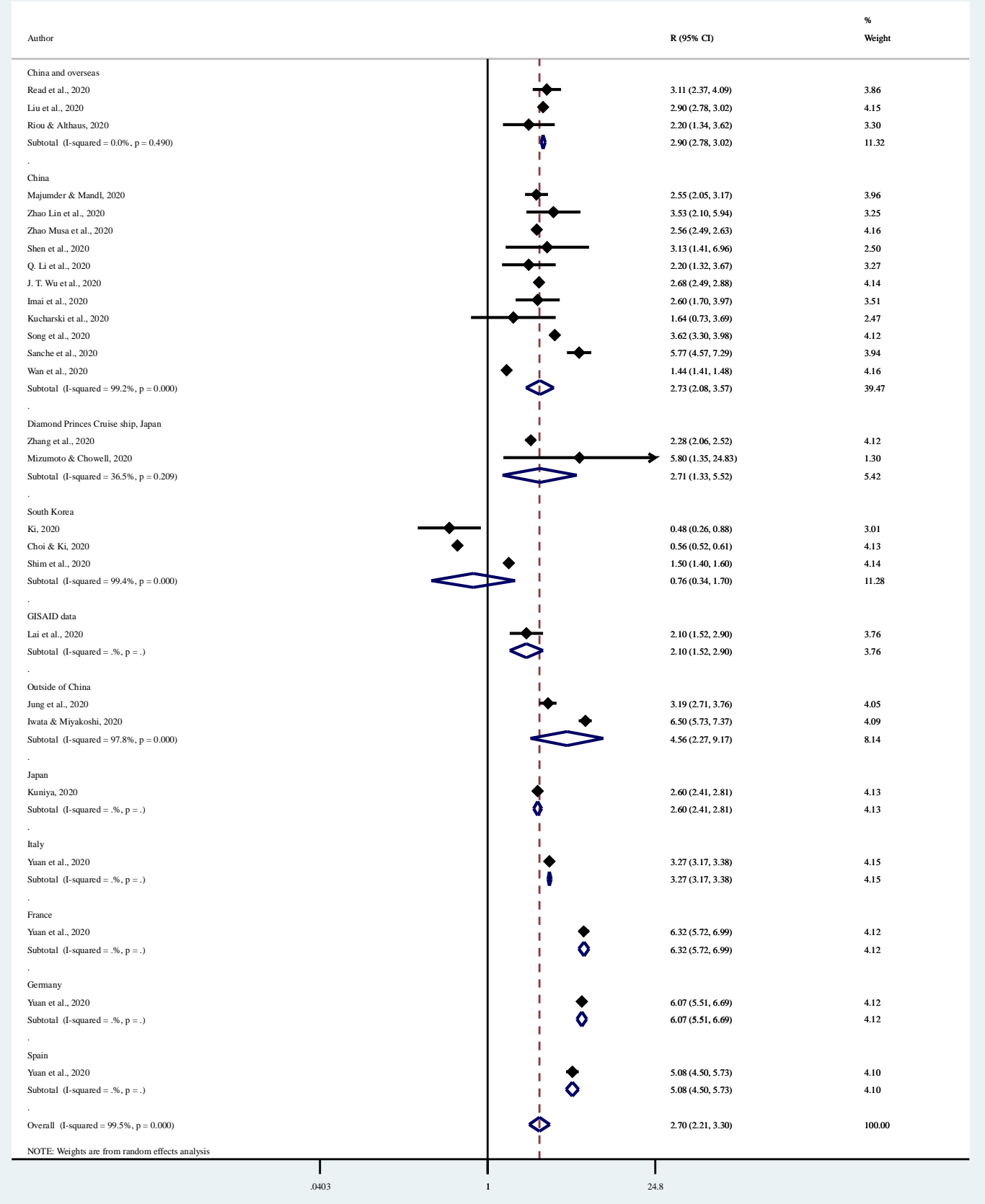

Supplementary Figure 2: Estimated reproductive number of COVID-19 across countries 
medRxiv preprint doi: https://doi.org/10.1101/2020.05.23.20111021; this version posted May 31, 2020. The copyright holder for this preprint (which was not certified by peer review) is the author/funder, who has granted medRxiv a license to display the preprint in perpetuity.

\section{It is made available under a CC-BY-NC 4.0 International license .}

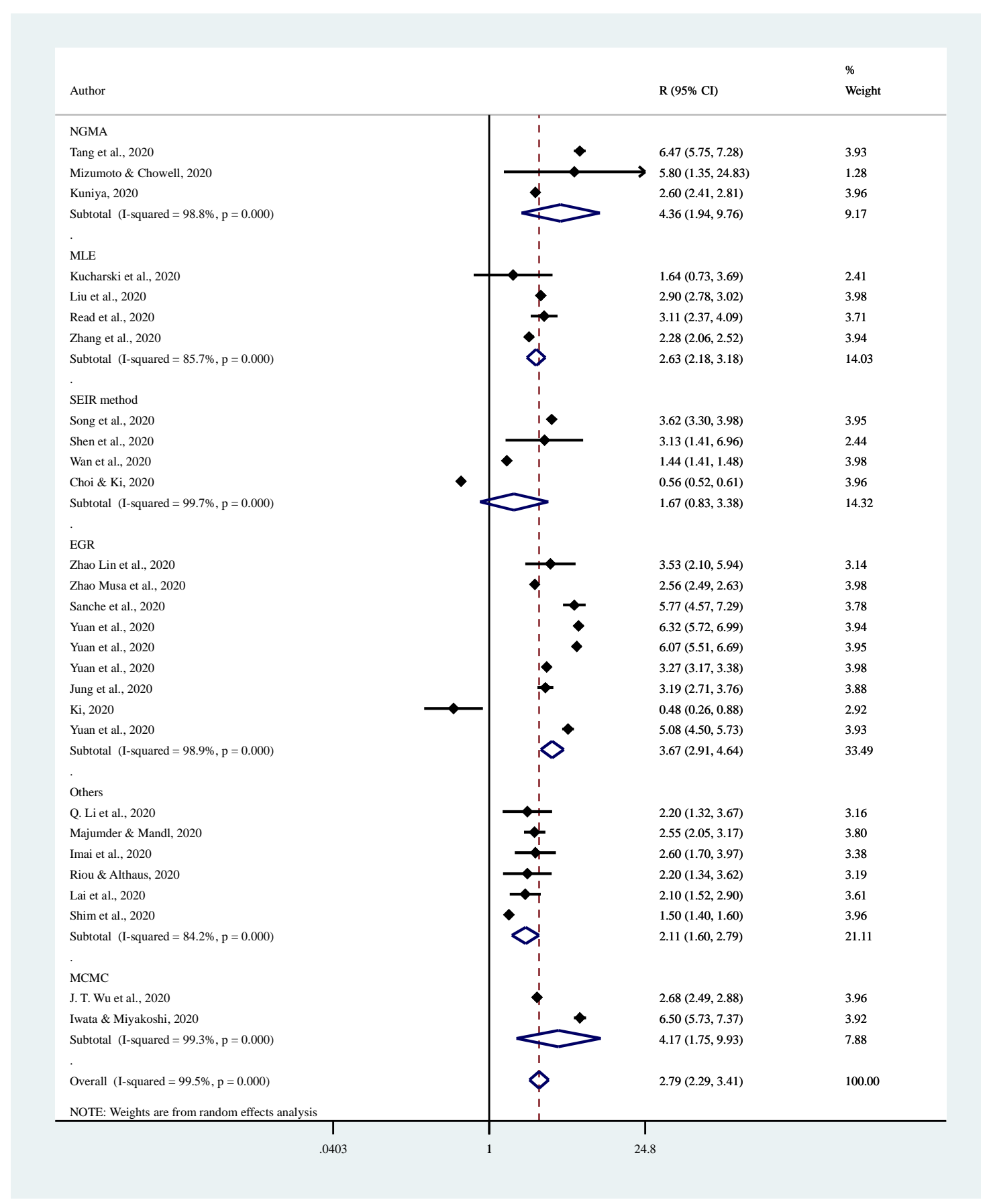

Supplementary Figure 3: Estimated reproductive number of COVID-19 across methods used to estimate 
medRxiv preprint doi: https://doi.org/10.1101/2020.05.23.20111021; this version posted May 31, 2020. The copyright holder for this preprint (which was not certified by peer review) is the author/funder, who has granted medRxiv a license to display the preprint in perpetuity.

It is made available under a CC-BY-NC 4.0 International license .

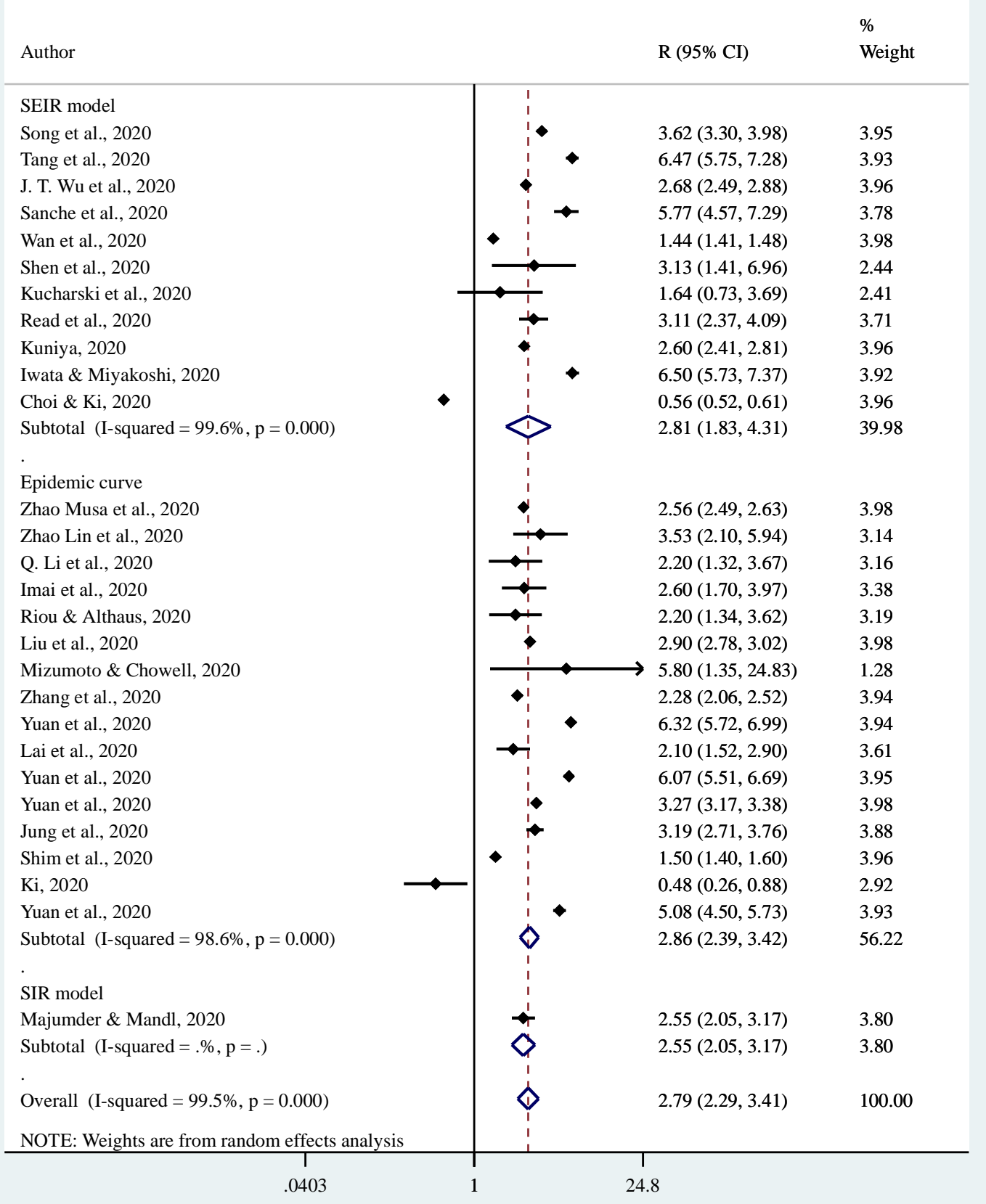

Supplementary Figure 4: Estimated reproductive number of COVID-19 across models used to estimate 
medRxiv preprint doi: https://doi.org/10.1101/2020.05.23.20111021; this version posted May 31, 2020. The copyright holder for this preprint (which was not certified by peer review) is the author/funder, who has granted medRxiv a license to display the preprint in perpetuity.

It is made available under a CC-BY-NC 4.0 International license .

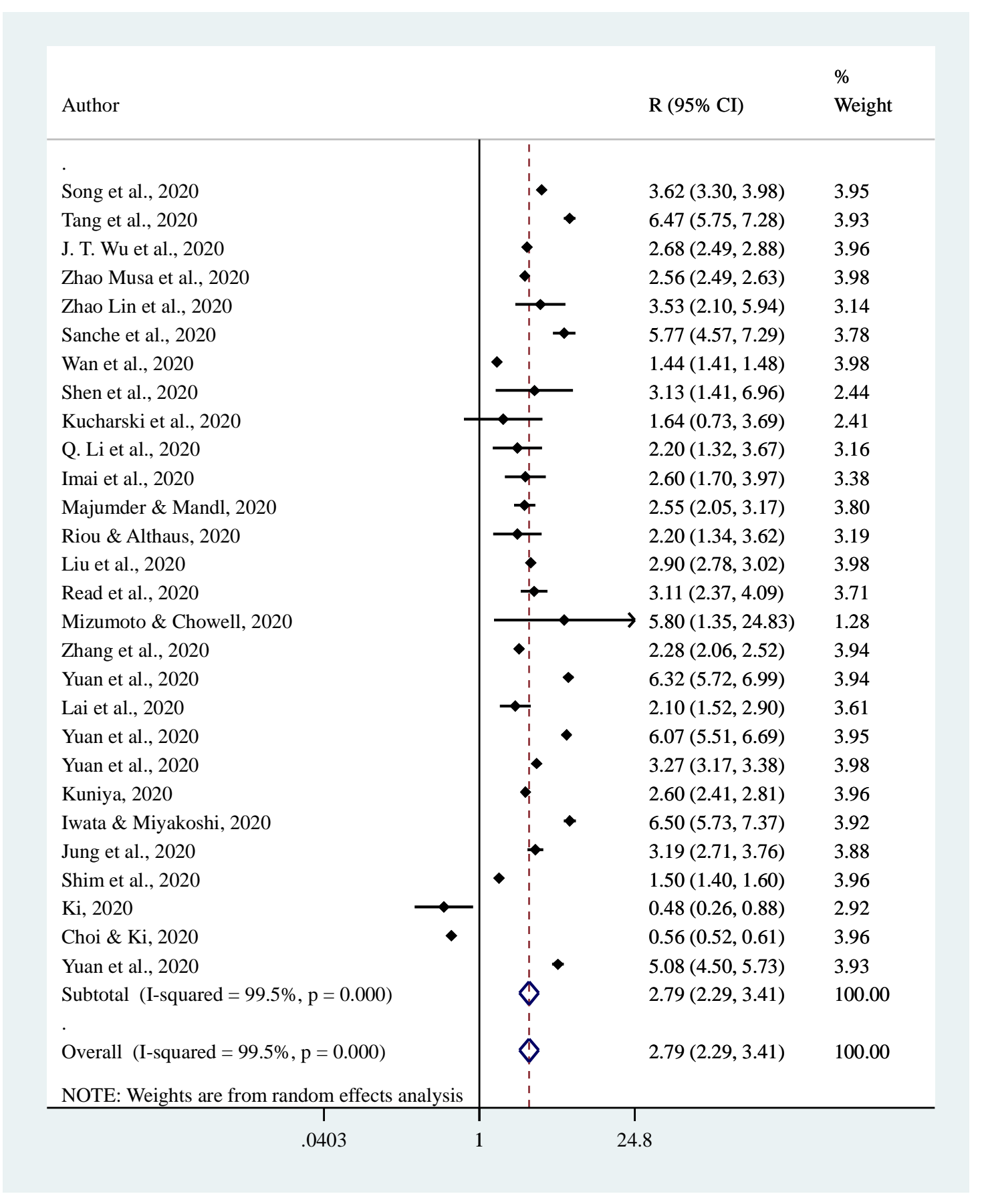

Supplementary Figure 5: Estimated reproductive number of COVID-19 across the number of cases considered to estimate 
medRxiv preprint doi: https://doi.org/10.1101/2020.05.23.20111021; this version posted May 31, 2020. The copyright holder for this preprint (which was not certified by peer review) is the author/funder, who has granted medRxiv a license to display the preprint in perpetuity.

It is made available under a CC-BY-NC 4.0 International license.

\begin{tabular}{|c|c|c|c|}
\hline Section/topic & $\#$ & Checklist item & $\begin{array}{l}\text { Reported } \\
\text { on page } \\
\#\end{array}$ \\
\hline \multicolumn{4}{|l|}{ TITLE } \\
\hline Title & 1 & Identify the report as a systematic review, meta-analysis, or both. & 2 \\
\hline \multicolumn{4}{|l|}{ ABSTRACT } \\
\hline $\begin{array}{l}\text { Structured } \\
\text { summary }\end{array}$ & 2 & $\begin{array}{l}\text { Provide a structured summary including, as applicable: } \\
\text { background; objectives; data sources; study eligibility criteria, } \\
\text { participants, and interventions; study appraisal and synthesis } \\
\text { methods; results; limitations; conclusions and implications of key } \\
\text { findings; systematic review registration number. }\end{array}$ & 2 \\
\hline \multicolumn{4}{|c|}{ INTRODUCTION } \\
\hline Rationale & 3 & $\begin{array}{l}\text { Describe the rationale for the review in the context of what is } \\
\text { already known. }\end{array}$ & 4 \\
\hline Objectives & 4 & $\begin{array}{l}\text { Provide an explicit statement of questions being addressed with } \\
\text { reference to participants, interventions, comparisons, outcomes, } \\
\text { and study design (PICOS). }\end{array}$ & 4 \\
\hline \multicolumn{4}{|l|}{ METHODS } \\
\hline $\begin{array}{l}\text { Protocol and } \\
\text { registration }\end{array}$ & 5 & $\begin{array}{l}\text { Indicate if a review protocol exists, if and where it can be } \\
\text { accessed (e.g., Web address), and, if available, provide } \\
\text { registration information including registration number. }\end{array}$ & 6 \\
\hline $\begin{array}{l}\text { Eligibility } \\
\text { criteria }\end{array}$ & 6 & $\begin{array}{l}\text { Specify study characteristics (e.g., PICOS, length of follow-up) } \\
\text { and report characteristics (e.g., years considered, language, } \\
\text { publication status) used as criteria for eligibility, giving rationale. }\end{array}$ & 7 \\
\hline $\begin{array}{l}\text { Information } \\
\text { sources }\end{array}$ & 7 & $\begin{array}{l}\text { Describe all information sources (e.g., databases with dates of } \\
\text { coverage, contact with study authors to identify additional } \\
\text { studies) in the search and date last searched. }\end{array}$ & 7 \\
\hline Search & 8 & $\begin{array}{l}\text { Present full electronic search strategy for at least one database, } \\
\text { including any limits used, such that it could be repeated. }\end{array}$ & 7 \\
\hline Study selection & 9 & $\begin{array}{l}\text { State the process for selecting studies (i.e., screening, eligibility, } \\
\text { included in systematic review, and, if applicable, included in the } \\
\text { meta-analysis). }\end{array}$ & 7 \\
\hline $\begin{array}{l}\text { Data collection } \\
\text { process }\end{array}$ & 10 & $\begin{array}{l}\text { Describe method of data extraction from reports (e.g., piloted } \\
\text { forms, independently, in duplicate) and any processes for } \\
\text { obtaining and confirming data from investigators. }\end{array}$ & 8 \\
\hline Data items & 11 & $\begin{array}{l}\text { List and define all variables for which data were sought (e.g., } \\
\text { PICOS, funding sources) and any assumptions and } \\
\text { simplifications made. }\end{array}$ & 8 \\
\hline $\begin{array}{l}\text { Risk of bias in } \\
\text { individual } \\
\text { studies }\end{array}$ & 12 & $\begin{array}{l}\text { Describe methods used for assessing risk of bias of individual } \\
\text { studies (including specification of whether this was done at the } \\
\text { study or outcome level), and how this information is to be used in } \\
\text { any data synthesis. }\end{array}$ & 8 \\
\hline $\begin{array}{l}\text { Summary } \\
\text { measures }\end{array}$ & 13 & $\begin{array}{l}\text { State the principal summary measures (e.g., risk ratio, difference } \\
\text { in means). }\end{array}$ & 8 \\
\hline $\begin{array}{l}\text { Synthesis of } \\
\text { results }\end{array}$ & 14 & $\begin{array}{l}\text { Describe the methods of handling data and combining results of } \\
\text { studies, if done, including measures of consistency }\left(\text { e.g., } I^{2} \text { ) for }\right. \\
\text { each meta-analysis. }\end{array}$ & 8 \\
\hline
\end{tabular}

Page 1 of 2 
medRxiv preprint doi: https://doi.org/10.1101/2020.05.23.20111021; this version posted May 31, 2020. The copyright holder for this preprint (which was not certified by peer review) is the author/funder, who has granted medRxiv a license to display the preprint in perpetuity. It is made available under a CC-BY-NC 4.0 International license .

\begin{tabular}{|c|c|c|c|}
\hline & & & $\overline{\#}$ \\
\hline $\begin{array}{l}\text { Risk of bias } \\
\text { across studies }\end{array}$ & 15 & $\begin{array}{l}\text { Specify any assessment of risk of bias that may affect the } \\
\text { cumulative evidence (e.g., publication bias, selective reporting } \\
\text { within studies). }\end{array}$ & 8 \\
\hline $\begin{array}{l}\text { Additional } \\
\text { analyses }\end{array}$ & 16 & $\begin{array}{l}\text { Describe methods of additional analyses (e.g., sensitivity or } \\
\text { subgroup analyses, meta-regression), if done, indicating which } \\
\text { were pre-specified. }\end{array}$ & 8 \\
\hline \multicolumn{4}{|l|}{ RESULTS } \\
\hline Study selection & 17 & $\begin{array}{l}\text { Give numbers of studies screened, assessed for eligibility, and } \\
\text { included in the review, with reasons for exclusions at each stage, } \\
\text { ideally with a flow diagram. }\end{array}$ & $9-17$ \\
\hline $\begin{array}{l}\text { Study } \\
\text { characteristics }\end{array}$ & 18 & $\begin{array}{l}\text { For each study, present characteristics for which data were } \\
\text { extracted (e.g., study size, PICOS, follow-up period) and provide } \\
\text { the citations. }\end{array}$ & $9-17$ \\
\hline $\begin{array}{l}\text { Risk of bias } \\
\text { within studies }\end{array}$ & 19 & $\begin{array}{l}\text { Present data on risk of bias of each study and, if available, any } \\
\text { outcome level assessment (see item 12). }\end{array}$ & $9-17$ \\
\hline $\begin{array}{l}\text { Results of } \\
\text { individual } \\
\text { studies }\end{array}$ & 20 & $\begin{array}{l}\text { For all outcomes considered (benefits or harms), present, for } \\
\text { each study: (a) simple summary data for each intervention group } \\
\text { (b) effect estimates and confidence intervals, ideally with a forest } \\
\text { plot. }\end{array}$ & $9-17$ \\
\hline $\begin{array}{l}\text { Synthesis of } \\
\text { results }\end{array}$ & 21 & $\begin{array}{l}\text { Present results of each meta-analysis done, including confidence } \\
\text { intervals and measures of consistency. }\end{array}$ & $9-17$ \\
\hline $\begin{array}{l}\text { Risk of bias } \\
\text { across studies }\end{array}$ & 22 & $\begin{array}{l}\text { Present results of any assessment of risk of bias across studies } \\
\text { (see Item 15). }\end{array}$ & $9-17$ \\
\hline $\begin{array}{l}\text { Additional } \\
\text { analysis }\end{array}$ & 23 & $\begin{array}{l}\text { Give results of additional analyses, if done (e.g., sensitivity or } \\
\text { subgroup analyses, meta-regression [see Item 16]). }\end{array}$ & $9-17$ \\
\hline \multicolumn{4}{|l|}{ DISCUSSION } \\
\hline $\begin{array}{l}\text { Summary of } \\
\text { evidence }\end{array}$ & 24 & $\begin{array}{l}\text { Summarize the main findings including the strength of evidence } \\
\text { for each main outcome; consider their relevance to key groups } \\
\text { (e.g., healthcare providers, users, and policy makers). }\end{array}$ & 18 \\
\hline Limitations & 25 & $\begin{array}{l}\text { Discuss limitations at study and outcome level (e.g., risk of bias), } \\
\text { and at review-level (e.g., incomplete retrieval of identified } \\
\text { research, reporting bias). }\end{array}$ & $19-20$ \\
\hline Conclusions & 26 & $\begin{array}{l}\text { Provide a general interpretation of the results in the context of } \\
\text { other evidence, and implications for future research. }\end{array}$ & 20 \\
\hline \multicolumn{4}{|l|}{ FUNDING } \\
\hline Funding & 27 & $\begin{array}{l}\text { Describe sources of funding for the systematic review and other } \\
\text { support (e.g., supply of data); role of funders for the systematic } \\
\text { review. }\end{array}$ & 21 \\
\hline
\end{tabular}

From: Moher D, Liberati A, Tetzlaff J, Altman DG, The PRISMA Group (2009). Preferred Reporting Items for Systematic Reviews and Meta-Analyses: The PRISMA Statement. PLoS Med 6(7): e1000097. doi:10.1371/journal.pmed1000097 For more information, visit: www.prisma-statement.org.

Page 2 of 2 